
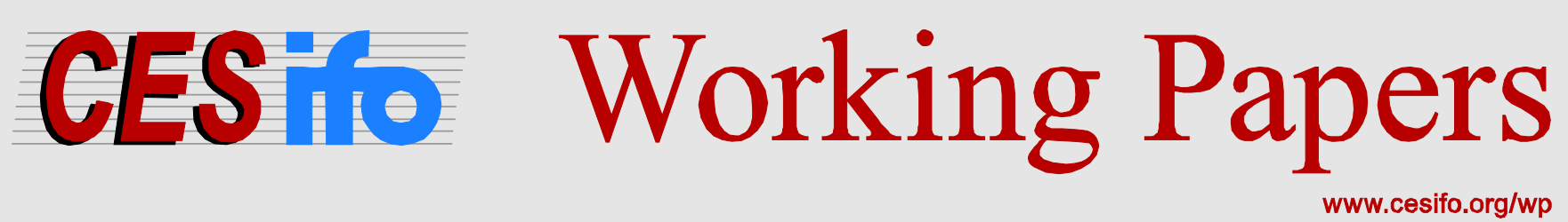

\title{
The Output Costs of Hard and Soft Sovereign Default
}

\author{
Christoph Trebesch \\ Michael Zabel
}

\author{
CESIFO WORKING PAPER NO. 6143 \\ CATEgory 7: MONETARY POLICY AND INTERNATIONAL FINANCE \\ OCTOBER 2016
}

An electronic version of the paper may be downloaded

- from the SSRN website:

- from the RePEc website:

- from the CESifo website: WwW.SSRN.com

www.RePEc.org

www.CESifo-group.org/wp 


\title{
The Output Costs of Hard and Soft Sovereign Default
}

\begin{abstract}
How costly are sovereign debt crises? In this paper we study output losses during sovereign default and debt renegotiation episodes since 1980. In contrast to previous work, we account for the severity of default and not only for its occurrence. Specifically, we distinguish between "hard" and "soft" defaults, using new data on debtor payment and negotiation behavior and on the size of haircuts towards private external creditors. We show that hard defaults are associated with a much steeper drop in GDP, of up to ten percent, compared to soft defaults, and address concerns of reverse causality and omitted variable bias. The results question the standard assumption that defaults trigger fixed and lump-sum costs. Instead, our findings are consistent with models assuming proportional output costs of default.
\end{abstract}

JEL-Codes: F340, F410, H630, G010.

Keywords: sovereign debt crises, debt restructuring, economic growth, reputation.

\author{
Christoph Trebesch* \\ University of Munich \\ Department of Economics \\ Schackstraße 4 \\ Germany-80539 Munich \\ christoph.trebesch@econ.lmu.de
}

\author{
Michael Zabel \\ University of Munich \\ Chair of Macroeconomics \\ Ludwigstraße 28 \\ Germany-80539 Munich \\ michael.zabel@econ.lmu.de
}

*corresponding author

This version: 28.08.2016

We thank Henrik Enderlein, Gerhard Illing, Julian Schumacher, Uwe Sunde, Laura von Daniels, and participants in the Munich Macro Seminar for very helpful comments and suggestions. We build on the basic idea of the paper "The Cost of Aggressive Sovereign Debt Policies" (Trebesch, 2009), but use a different dependent variable and empirical approach. This paper supersedes that draft. All remaining errors are our own. 


\section{Introduction}

How costly is a sovereign default? Answering this question is important for our theoretical understanding of sovereign debt $^{1}$ and for policymakers in crisis situations. Past empirical work on the cost of default commonly relied on a binary debt crisis measure of default versus non-default. In this paper, we propose the use of more continuous default measures to study output losses during debt crises. Specifically, we distinguish between cases of "hard" and "soft" default based on a new procedural index that tracks a government's payment and negotiation behavior vis-à-vis foreign creditors during a default spell. We also use a continuous outcome measure of debt crises, namely the size of creditor losses or "haircuts" captured at the end of a debt crisis. Our results show that the output loss during a debt crisis is much deeper for episodes of "hard" defaults. This new stylized fact suggests that not only the incidence of default matters, as implied by much of the previous literature, but also the scope and severity of default.

Our research design is motivated by the striking differences between debt crisis events, as documented in case studies by Roubini and Setser (2004) or Sturzenegger and Zettelmeyer (2007). On the one hand, there are cases such as Russia during the 1990s, Ecuador 2008/2009 or Argentina 2002-2005, in which governments opted for a unilateral payment moratorium, engaged in anti-creditor rhetoric, and at times even refused to negotiate with their foreign banks and bondholders. These confrontational defaults also involved high creditor losses (haircuts) of up to 70\%. On the other hand, there are debt crises that got resolved in a consensual manner, with close creditor consultations, little (or no) missed payments, and low haircuts of around 10-20\%. Examples include Ukraine in 1999/2000 (and in 2015) or Uruguay in 2003.

The differences in crisis resolution strategies are influenced by a central trade-off for distressed governments: on the one hand, governments can decide to adopt a confrontational policy towards external creditors, by halting all debt payments, by demanding high haircuts (debt relief), and by delaying negotiations and thereby postponing the day until debt servicing is resumed. This strategy frees up resources that can be distributed to the domestic population during the default and may buy political support at home. However, one can expect deep haircuts and confrontational debtor behavior to also cause negative spillovers on the domestic economy and the financial sector (see Panizza et al., 2009). One potential channel behind this is reputation: "hard" defaults

\footnotetext{
${ }^{1}$ Since Eaton and Gersovitz (1981), assumptions on the cost of default have crucially influenced the setup and results of sovereign debt models (see the surveys by Eaton and Fernandez, 1995; Panizza et al., 2009; Aguiar and Amador, 2014).
} 
as in Argentina 2001 are likely to send a negative signal about fundamentals and worsen country reputation more than "soft" defaults as in Uruguay 2003 (e.g. Cole and Kehoe, 1997). The expected outcome is a decline in access to external credit, less trade, less investment and, thus, a drop in GDP (see Mendoza and Yue, 2012). The alternative choice for governments in distress is to adopt a creditor-friendly stance, by continuing debt payments to foreign banks and bondholders and by demanding low haircuts (little debt relief). This strategy may mitigate the negative reputational effects of a default, but will shift the burden to the domestic population, which can expect higher taxes and less transfers during and after the default spell (D'Erasmo and Mendoza, 2016).

The main contribution of this paper is to take the heterogeneity in sovereign debt crises seriously and to show in a stylized form that the output losses in a default increase in the severity of default. This result casts doubt on one of the most widely used assumptions in quantitative sovereign debt models, namely that defaults trigger output costs that are fixed and lump-sum, irrespective of the type of default or the size of haircuts. The notion that the output costs of default are proportional (rather than lump-sum) shapes modeling in a fundamental way and also has "far-reaching implications for policy analysis", as emphasized by Corsetti and Dedola (2012).

We proceed in two steps. First, we analyze output during debt crises, since defaults can take many years to resolve (sometimes more than a decade). In a second step, we focus on post-crisis growth, i.e. output performance after countries exit default with a debt restructuring. Our main explanatory variable during default is a measure on "government coerciveness" towards creditors. This "coerciveness index" is based on a new database on debt crisis resolution processes by Enderlein et al. (2012), which categorizes a government's debtor policies on a scale from 1 (very creditor-friendly) to 10 (very confrontational). The dataset tracks government actions towards private external creditors for each year throughout a debt crisis along nine dimensions of payment and negotiation behavior. Debtor coerciveness shows a strong variation not only across debt crises and defaulting countries, but also within crisis spells. This is advantageous compared to a simple default dummy, since it allows us to exploit both the cross-sectional and the time-series variation in debtor behavior. Our main explanatory variable after debt crises is the size of haircuts, i.e. the scope of creditor losses implied by a debt restructuring at the end of a default spell as measured by Cruces and Trebesch (2013). In sum, we thus trace the output performance in "hard" and "soft" defaults over the entire crisis episode, starting from the first missed payments to the conclusion of the debt restructuring and the subsequent post-default period. 
We find that coercive government behavior during default is associated with a significantly worse output performance. In "hard" defaults, real GDP sees a strong and long-lasting decline, while this is not the case in "soft" defaults in which the government opted for a consensual stance towards creditors. This descriptive finding is confirmed when we use annual per capita real growth as dependent variable and regress it on our proxies for hard and soft defaults as well as economic fundamentals and fixed effects. However, with cross-country panel data, it is difficult to identify the causal effect of

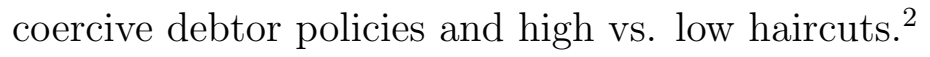

In particular, we face two main identification challenges: (i) omitted variable bias, as common shocks and/or socio-political changes could affect both output and coerciveness/haircuts, and (ii) reverse causality, since changes in output could explain the type of default and not vice versa. To address the problem of omitted variable bias, we include country and time fixed effects and a host of economic and political control variables, including the set of macro controls commonly used in the growth literature, but also crisis duration, banking and currency crises, IMF programs, and political risk. We also include a lagged dependent variable as a control and account for country-specific time trends. Regarding reverse causality, we test whether past output performance (growth) helps to predict debtor coerciveness later on, but find no evidence that past economic growth drives current coercive behavior. Moreover, we attempt to disentangle the role of expected and unexpected government coerciveness and tease out the surprise component in debtor behavior by using forward-looking, start-of-year country credit ratings. Taken together, the result of these checks are encouraging and help to alleviate endogeneity concerns. Despite this, we cannot rule out that some unobserved, time-varying confounder drives our results, so that the coefficients should be interpreted with caution. We show strong conditional correlations and do not claim to show causal effects.

With this caveat in mind, we show that the estimated coefficients for debtor coerciveness during default are both large and robust. In our most demanding specification, moving from a soft default as in Uruguay 2003, to a coercive default as in Argentina of 2005, is associated with a three percentage point lower growth rate in each default year. Because debt crisis spells span more than 5 years, on average, this correlation coefficient would translate to a more than 10 percentage point lower GDP level in hard defaults as opposed to soft defaults (in the short- and medium-term).

\footnotetext{
${ }^{2}$ See Hebert and Schreger (2016) for a smart strategy to identify the output cost of default in one crisis case, namely Argentina 2014.
} 
While the differences are large during ongoing crisis spells (in each year of default), we find no evidence for long-term effects post-crisis, i.e. once the country finally receives debt relief and exits default. The coefficient of coercive debt policies is no longer significant after the default exit and we also find no robust relationship between the size of haircuts and post-crisis growth performance. ${ }^{3}$ This result may be due to the positive impact of debt relief on post-crisis investment and growth, as suggested by Reinhart and Trebesch (2016a). Another explanation is that countries settle with creditors and exit default only after long delays and when growth prospects have already improved (see Benjamin and Wright, 2009).

Our findings have implications for theory. Most importantly, they are not consistent with the idea of lump-sum default costs. Most dynamic general equilibrium models with defaultable debt assume fixed output costs of a default (for example Aguiar and Gopinath, 2006; Yue, 2010; Arellano and Ramanarayanan, 2012; Hatchondo and Martinez, 2012; Chatterjee and Eyigungor, 2012; Hatchondo et al., 2014; Aguiar et al., 2013; Cole et al., 2016, to name just a few). For calibration purposes, this literature often uses an output loss of two percent in default years. ${ }^{4}$ Our results indicate that the costs of default can be much higher or lower than that, depending on the severity of default. We thus provide empirical backing for a small number of theory papers in which the costs of default are proportional, that is, increase in the size of (expected) haircuts (see e.g. Calvo, 1988; Bulow and Rogoff, 1989; Bolton and Jeanne, 2007; Corsetti and Dedola, 2012; Adam and Grill, 2013; Arellano et al., 2013). ${ }^{5}$

Regarding the empirical literature, we are among the first to account for the magnitude and the severity of sovereign defaults. Several earlier studies have emphasized the important differences across debt crises events. Obstfeld and Taylor (2003), for example, distinguish between "partial" and "full" defaulters, while Eichengreen (1991) refers to "light" vs. "heavy" defaults. However, no contribution has yet quantitatively analyzed how different crisis characteristics affect a country's GDP growth in a large sample of countries and crises. Most papers on the output costs of debt crises use a binary default measure by Standard \& Poor's and conclude that defaults are associated with a steep drop in output, with estimates ranging from two to six percentage points lower growth, depending on the sample and estimation method (see, in particular, Sturzenegger, 2004; Borensztein and Panizza, 2009; Furceri and Zdzienicka, 2012;

\footnotetext{
${ }^{3}$ See Kuvshinov and Zimmermann (2016) for an analysis on the short vs. long-term impact of sovereign defaults on growth.

${ }^{4}$ This figure has been used with reference to Sturzenegger (2004).

${ }^{5}$ For corporate debt, the assumption of proportional default costs is more established, see e.g. Zame (1993) and Dubey et al. (2005).
} 
Gornemann, 2016; Kuvshinov and Zimmermann, 2016). De Paoli et al. (2009) show that the fall in output is particularly large when defaults are accompanied by banking and/or currency crises. Tomz and Wright (2007) show that the relationship between default and output since 1820 is unexpectedly weak. Levy-Yeyati and Panizza (2011) use quarterly data to show that, on average, output contractions precede defaults and that growth picks up after the quarter in which default occurs. More recently, Hebert and Schreger (2016) tease out the cost of default in Argentina by focusing on exogenous court rulings in New York and their effect on Argentinean stocks.

Despite this large literature, there is barely any work on the effects of different types of debt crisis resolution (see also the empirical survey by Tomz and Wright, 2013). In line with Cruces and Trebesch (2013), Asonuma and Trebesch (2016) and Catao and Mano (2015), we conclude that it is crucial to account for the heterogeneity of debt crises when studying their consequences. ${ }^{6}$ A dichotomous measure may be overly simplistic and can introduce measurement error.

\section{Theoretical considerations}

The theory literature offers explanations why defaults are economically costly, and why output costs could be larger in "hard" defaults with confrontational government behavior and high haircuts. One group of papers emphasizes the role of reputational spillovers and signaling. Grossman and van Huyck (1988) suggest that lenders differentiate between excusable defaults and cases of inexcusable debt repudiation. High creditor losses and coercive debt policies that are not justified by a bad state of the economy could thus lead to a deterioration of country reputation and, thereby, to "collateral damage" on the domestic economy and lower output. ${ }^{7}$ Relatedly, Cole and Kehoe $(1997,1998)$ develop a model of generalized reputation. Governments who are deemed untrustworthy in one field will also be seen as untrustworthy in other fields. More recently, Sandleris (2008) argues that the repayment behavior of sovereigns acts as a signal on country fundamentals and government willingness (or ability) to undertake reforms and to pro-

\footnotetext{
${ }^{6}$ Asonuma and Trebesch (2016) study output losses in preemptive vs. post-default debt restructurings. Relatedly, a recent paper by Marchesi (2016) also uses the haircut data by Cruces and Trebesch (2013) and confirms our finding that more severe defaults (with high haircuts) are associated with lower growth. See also Trebesch (2009) for a similar setup using the coerciveness index. This paper supersedes that draft.

${ }^{7}$ Although we focus on proxies of coercive debtor behavior, this paper does not explicitly test for the cost of "excusable" vs. "inexcusable" defaults.
} 
tect property rights. Expropriative debt policies could thus affect agents' beliefs both at home and abroad, leading to less investments and lower growth.

These negative signaling and reputation effects can result in lower growth due to several channels. Eaton and Gersovitz (1981) propose that a default results in exclusion from international capital markets, which undermines a country's ability to smooth consumption and invest. ${ }^{8}$ Bulow and Rogoff (1989) emphasize the role of sanctions, such as trade sanctions or legal sanctions, which increase in the share of debt that is repudiated, resulting in a disruption of goods and asset trade and, thus, lower growth. More recent contributions have emphasized spillovers on trade, investments, productivity and corporate access to foreign credit (Rose, 2005; Arteta and Hale, 2008; Trebesch, 2009; Mendoza and Yue, 2012; Sandleris and Wright, 2014), as well as the impact on financial intermediation and the banking sector (Bolton and Jeanne, 2011; Gennaioli et al., 2014b,a; Bocola, 2015).

The intuition behind our analysis is that the collateral damage of a sovereign default is likely to be larger in hard default episodes, thus resulting in lower growth. Moreover, there might be a direct financial sector channel: Gennaioli et al. (2014a) show that the spillovers of a default on domestic and foreign banks are larger the higher the haircut (using the same haircut data as in this paper). ${ }^{9}$

Taken together, these considerations help to rationalize our main empirical finding that high expected haircuts and confrontational debt policies are associated with lower growth during default.

Regarding the post-default period, there are at least two competing channels. On the one hand, high haircuts and confrontational debtor policies could have lagged negative effects on growth, e.g. due to the spillover effects described above. On the other hand, there is the channel of debt relief, which goes in the opposite direction. High haircuts (and confrontational policies leading to high haircuts) reduce government indebtedness more significantly. This debt relief effect can allow countries to exit a debt overhang situation and reduces the risk of future default, possibly improving growth prospects (see Arslanalp and Henry, 2005; Reinhart et al., 2012; Reinhart and Trebesch, 2016a). While we account for debt relief by controlling for the debt to GDP ratio after

\footnotetext{
${ }^{8}$ In Kletzer and Wright (2000) and Wright (2002) exclusion and punishment does not occur in equilibrium. However, recent models in which defaults do occur in equilibrium continue to assume credit market exclusion, at least temporary exclusion (e.g. Arellano, 2008; Yue, 2010).

${ }^{9}$ As in most of the existing literature, we do not analyze the underlying channels at work here, meaning that we do not test whether the observed link between default and growth can be explained by sanctions, reputational damage and/or signaling. Indeed, it is very challenging to identify the reputation or signaling channels empirically.
} 
the restructuring, the link between haircuts and post-default growth is theoretically ambiguous and, thus, an empirical question.

\section{$3 \quad$ Empirical approach and data}

Existing work on the link between default and growth, such as Sturzenegger (2004) and Borensztein and Panizza (2009), typically regresses annual per capita real growth on a dummy for the start of default, lagged values of this dummy, and a set of standard control variables as used in the cross-country growth literature. This binary categorisation of sovereign defaults hides the substantial variation in crisis characteristics. In the following, we therefore propose using more continuous measures of default severity.

\subsection{Classifying hard and soft sovereign defaults}

We distinguish between "hard" and "soft" defaults by building on two distinct empirical measures on the heterogeneity of debt crisis events. The first measure is the index of debtor coerciveness constructed by Enderlein et al. (2012), which is procedural and captures differences in crisis characteristics during default, in particular the payment and negotiation behavior of governments towards foreign creditors. The second measure is the main outcome of debt renegotiations, namely the size of creditor losses or "haircuts" implied in debt restructuring agreements that resolve a default. Based on these two measures, we seek to trace the relationship between debtor default behavior and GDP over the entire debt crisis episode - from the start of default, over the whole default and debt renegotiation period (which lasts an average of 6.3 years in our sample) and up to five years after the crisis ends with a final restructuring.

The coerciveness and haircut measures both have their strengths and weaknesses for the purpose of this analysis. The main advantage of using haircuts is that it is an intuitive measure that can be computed based on observable terms of a debt restructuring agreement. The disadvantage, however, is that haircuts are a snapshot measure that can only be observed once - at the end of a debt renegotiation period, which can take many years. An illustrative example is the default of Peru, whose debt crisis lasted from the mid-1980s until the late 1990s, when the default was finally cured with the Brady deal of 1997. During these 15 years, Peru's debt policy vis-à-vis its foreign creditors varied substantially. The government's stance was very confrontational after the inauguration of President Garcia in 1985, who immediately imposed a unilateral debt 
Figure 1: Stylized crisis timeline and research design

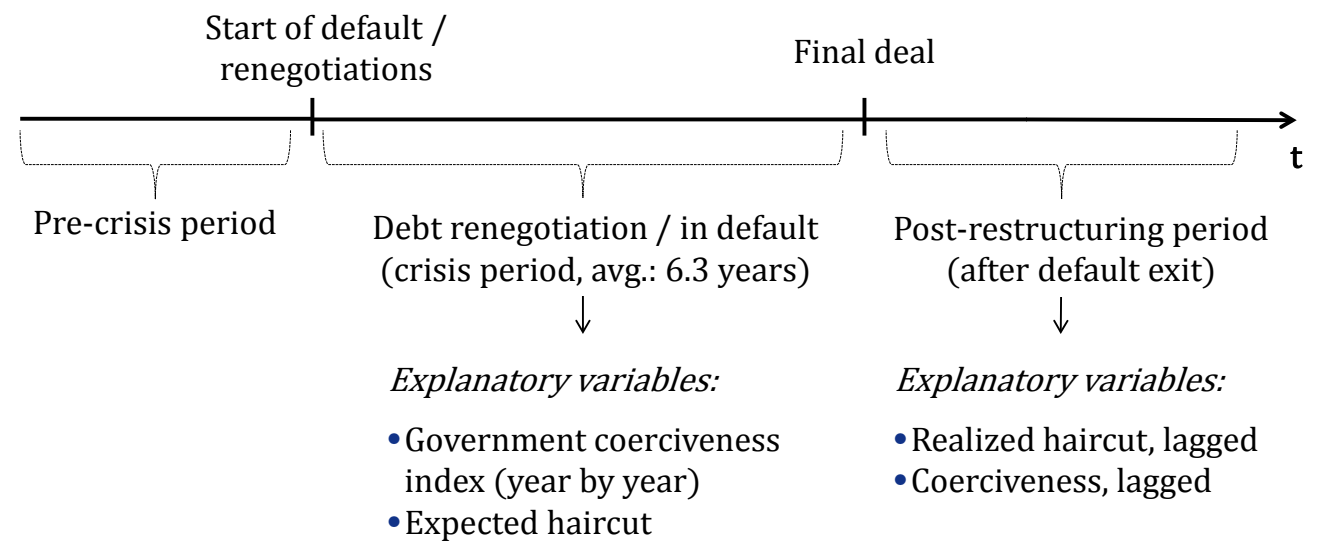

moratorium. After President Fujimori took over in 1990, Peru's debt policies became much more cooperative and negotiations were resumed. This variation in debtor policy is captured accurately by the coerciveness index ${ }^{10}$, while a haircut is only available for the end of default in 1997. In principle, one can make the argument that creditors quickly form expectations on the scope of losses which they are likely to suffer and that the expected haircut will be roughly in line with the realized final haircut. However, for longer crises, such as the one in Peru, it is far-fetched to use the 1997 haircut as a proxy for loss expectations in the mid- or late 1980s. The advantage of the index of debtor coerciveness is that it is time varying and observable for each year throughout the debt crisis. It therefore allows us to capture both the within-crisis variation and the cross-sectional variation in debtor policies. However, as any newly constructed index, the coerciveness index can be criticized as being too broad or too narrow, or for not using the right criteria or weighting scheme (see the detailed discussion in Enderlein et al., 2012).

Against this backdrop, we use both the procedural coerciveness index and the outcome variable haircuts to classify hard and soft defaults. Specifically, we focus on the coerciveness index as our main explanatory variable during a default spell, and use haircuts as our preferred measure for the post-default period. Our research design is illustrated in Figure 1, which shows a stylized debt crisis timeline.

\footnotetext{
${ }^{10}$ More specifically, the coerciveness index in Peru increases from 2 at the start of default in 1982 to 8 in the year 1985, when Garcia became president. Throughout Garcia's presidency, the index fluctuates at a value above 5 and then declines gradually after Fujimori takes office (from 5 in 1990 to 1 in the settlement year 1997).
} 


\subsection{The coerciveness index}

The index of debtor coerciveness (or coerciveness index) was coded from quantitative as well as qualitative sources, including 20,000 pages of articles from the financial press. The idea of categorising different types of debtor behavior towards creditors is not new. Authors like Aggarwal (1996), Andritzky (2006), Cline (2004) or Roubini (2004) all suggested that debt policies and restructuring processes vary on a spectrum from "soft" to "hard" or from "voluntary" to more "involuntary". However, Enderlein et al. (2012) provide the first comprehensive and systematic dataset suitable for econometric analysis.

The construction of the index mirrors the views of financial market participants, policymakers, and researchers on how fair debt restructuring processes should look like. An essential point of reference were the "good faith" criteria outlined in the IMF's lending into arrears policy International Monetary Fund $(1999,2002)$, as well as the list of best practices in the IIF's "Principles for Stable Capital Flows and Fair Debt Restructuring in Emerging Markets" (Institute of International Finance, 2013). These two "how to" manuals of fair debt restructuring play a central role in debt crises and are well known by officials and investors alike. They therefore shaped the way the sub-indicators of the coerciveness index were defined and coded. Also previous research on "coercive" defaults guided the index design, in particular the criteria proposed by Cline (2004) and Roubini (2004).

The final index captures coercive measures which governments adopt towards their private external creditors, such as foreign banks or bondholders. It consists of nine subindicators, each of which gauges observable government actions vis-à-vis creditors. Each sub-indicator is a dummy variable, which is coded as one if the respective action by the government can be observed in a given year, and zero otherwise. The sub-indicators can be grouped into two broad categories: (1) "Indicators of Payment Behavior", capturing government actions that have an immediate effect on the financial transfers to international banks or bondholders, and (2) "Indicators of Negotiation Behavior", measuring negotiation patterns and confrontational rhetoric of governments. By definition, the index is coded for debt crisis episodes only, where the start of a debt crisis is defined as either missed payments (legal default) or the announcement of a debt restructuring by a key government official (see section 3.4. below for more details).

Enderlein et al. (2012) give the exact definitions of and the theoretical rationale for each sub-indicator and provide the detailed coding procedures, descriptive statistics and stylized facts on the index. Here, we summarize each sub-indicator briefly. 
The indicators of government payment behavior during debt crises are the following:

1. Payments missed? (yes/no): The first sub-indicator is coded 1 whenever a government misses interest or principal payments on its bonds or commercial loans beyond the grace period. Accordingly, it takes the value of 0 whenever the sovereign manages to restructure its debt pre-emptively, before running into arrears. Most debt crises do involve missed payments, but there are many exceptions too. Examples of restructurings without missed payments include Algeria and Uruguay in the 1980s, or Uruguay in 2003.

2. Unilateral payment suspension? (yes/no) The second sub-indicator captures whether the sovereign did unilaterally suspend payments to its creditors, i.e. without a previous agreement with and/or consultations with creditors. This indicator enables us to differentiate between outright defaults on the one hand and "negotiated defaults" on the other (Bulow and Rogoff, 1989). Even in severe crises, officials can reach out to creditors and seek preventive debt roll-overs or other forms of bridge financing. Despite this, two thirds of payment suspensions occur unilaterally and without prior agreement or consent.

3. Full moratorium, incl. interest payments? (yes/no): The third indicator captures full moratoria, meaning the suspension of all sovereign debt payments to private creditors, including interest. Partial debt servicing is a recurring demand of banks and bondholders during debt crises and also the (Institute of International Finance, 2013) demands continuing interest payments as a sign of good faith. A complete suspension of payments can therefore be interpreted as particularly coercive debtor policy and signals a government's unwillingness to pay. Full moratoria only occur in around a quarter of all annual crisis observations.

4. Freeze on foreign assets? (yes/no): The fourth indicator is coded 1 when the government issues emergency decrees that effectively lead to a freeze of creditor assets in the country. Past crises have sometimes been accompanied by capital and exchange controls that prohibit domestic firms to service their debt to foreign banks or bondholders. This type of asset freezes are a particularly tough debtor policy and are observed only on rare occasions, e.g. in Argentina in 1982 and 2002, or in Ukraine and Pakistan in 1998. 
The indicators of government negotiation behavior during debt crises are:

5. Breakdown or refusal of negotiations? (yes/no): This indicator measures whether governments refuse to engage in negotiations with its creditors and/or whether government actions result in a breakdown of debt negotiations for a period of three months or more in a given year. Regular and continuous dialogue between the sovereign and its creditors are an essential prerequisite for the consensual solution of a debt crisis. Nonetheless, government-induced delays and refusals to negotiate are quite common and take place in almost half of all crisis years.

6. Explicit moratorium or default declaration? (yes/no): Does a key government actor (president, prime minister, minister of finance or economy, or the president of the central bank) officially proclaim the decision to default? Explicit default declarations are rare since most governments miss payments as quietly and discretely as possible. However, in cases such as Peru 1985, Ecuador 1999 and Argentina 2001, the decision to default was publicly announced and accompanied by anti-creditor rhetoric, thus resembling a "declaration of war" against foreign banks and bondholders.

7. Explicit threats to repudiate on debt? (yes/no): Does a key government actor publicly threaten to repudiate sovereign debt owed to foreign private creditors? Open threats to cancel debt payments or to impose an indefinite moratorium are rare, but they can be an effective strategy to extract more concessionary terms from creditors. Examples include repudiation threats of Chilean President Pinochet in 1986, or President Correa of Ecuador in 2008 who threatened to declare large parts of the government's foreign debt as "odious" and "illegitimate".

8. Data disclosure problems? (yes/no): This indicator captures data disclosure problems, i.e. cases in which the government refused to provide crucial debtrelated information and cases in which there is an open dispute due to inaccurate government data. The provision of reliable data on debt stocks or foreign exchange reserves constitutes a basic requirement for creditors to evaluate a country's capacity to repay and to assess the terms of a debt exchange proposal. Data-related disputes are therefore coded as a coercive action. Examples include Brazil 1987, Peru 1996 or Ecuador 2008/09 where data issues have been a central stumbling block for crisis resolution. 
Figure 2: Construction of the coerciveness index

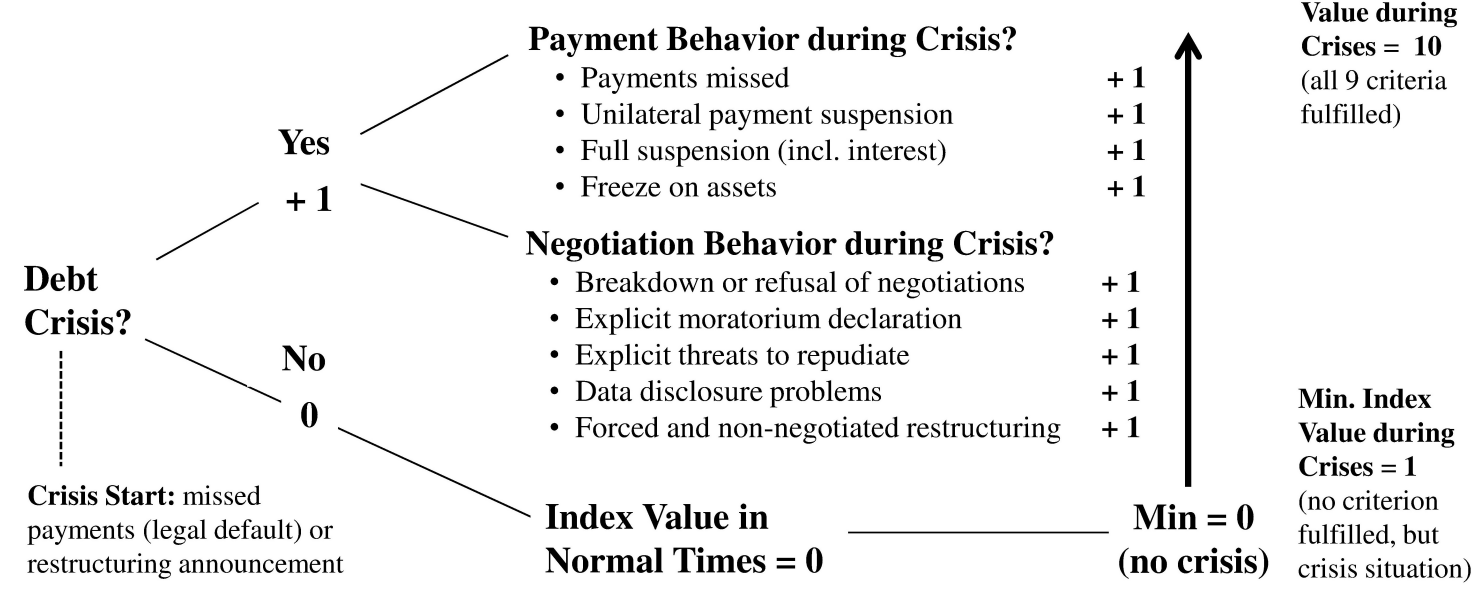

Note: This figure illustrates the construction of the coerciveness index. It is taken from Enderlein et al. (2012).

9. Forced and non-negotiated restructuring? (yes/no): The final indicator is coded 1 whenever the restructuring was not negotiated with creditors but unilaterally imposed by the government. The idea is to identify debt exchanges that are implemented without prior creditor consultations. Forced and non-negotiated restructurings are rare and constitute a strong sign of coercive debt policies. The restructuring of Argentina in 2005 as well as a forced debt roll-over in Peru of 1986 are among the few examples.

The final coerciveness index is additive, defined as equally weighted sum of the 9 binary sub-indicators. ${ }^{11}$ An index value of 0 applies in normal times without default or debt renegotiations, i.e. if the government pays back its debt in full and on time. A value of 1 is assigned if a government announces a debt restructuring (crisis start), but does not fulfill any of the 9 coerciveness criteria in that year. This means that there are cases for which the index takes the value of 1 even if the country misses no payments (no legal default). For example, debt crisis spells like Uruguay 2003 or Algeria 1992 are categorized as 1, since both countries restructured their debt with a haircut, but without missing payments, without threats, and in close coordination with creditor groups. During debt crisis spells, the index thus ranges from a minimum of 1 , indicating a debt renegotiation period with very cooperative government behavior, to 10, for particularly aggressive debt policies and a full moratorium. Figure 2 illustrates

\footnotetext{
${ }^{11}$ The results are very similar when weighting the sub-indicators using principal component analysis.
} 
the construction of the coerciveness index graphically. Moreover, Figure A.1 in the Online Appendix shows the distribution of the coerciveness index and reports summary statistics for each sub-indicator.

\subsection{The size of haircuts}

We now move on to our second main explanatory variable: the size of haircuts negotiated between the government and its external creditors. This is the central outcome of the debt restructuring process. Since haircuts are a straightforward measure there is less need for detailed explanations as was the case for the coerciveness index above.

Specifically, we use the database of investor losses by Cruces and Trebesch (2013) that measures creditor haircuts in restructurings between 1970-2010 based on the methodology proposed by Sturzenegger and Zettelmeyer (2008) as:

$$
H_{S Z}=1-\frac{\text { Present Value of New Debt }(r)}{\text { Present Value of Old Debt }(r)}
$$

where $r$ is the discount factor employed to calculate the present value of old and new debt instruments.

Building on Cruces and Trebesch (2013) we focus on haircuts in "final" debt restructurings only. Final deals are those that enable countries to cure the default and exit a crisis spell without a renewed default in the following 4 years. This focus on final restructurings is in the spirit of related work such as Cline (1995), Arslanalp and Henry (2005) and Reinhart and Trebesch (2016a) who also study the outcome of final deals and pay less attention to intermediate restructurings like most debt operations of the 1980s that only implied short-term relief. Peru can again serve as an example, since its restructuring of 1983 is not coded as final, because it was merely a two-year debt rollover and did not cure the default. Indeed, Peru continued to miss payments and did so until 1997.

The number of final restructurings in our sample are 30 cases, including the Brady debt exchanges of the 1990s as well as all main recent emerging market bond exchanges such as Russia 2000 or Argentina 2005. Importantly, this haircut sample closely matches the sample for which we also have the prodedural coerciveness data (during default), so that we can directly compare results for both measures. Figure A.2 shows how the haircuts in our sample are distributed over time and reports basic summary statistics. 
Finally, Figure 3 shows a scatter plot of haircuts (in final deals) and the coerciveness index by debt crisis events (computed as average yearly index value for each crisis spell). As can be seen, the relationship between these two measures is very tight, with a correlation coefficient of close to 0.70. This suggests that coercive actions during default are a good predictor for the degree of realized creditor losses, i.e. for the size of haircuts that is negotiated at the end of a default spell.

Figure 3: Haircuts and coerciveness index - scatter plot

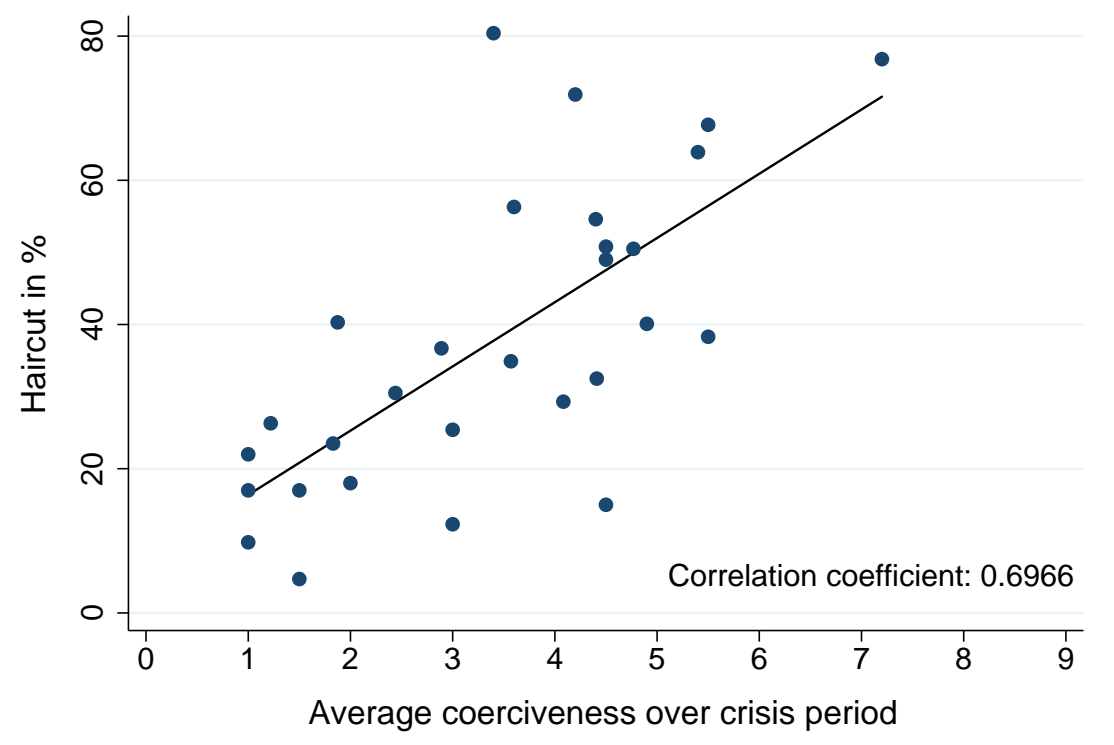

Note: This graph shows a scatter plot between the size of haircuts (in final restruturings of each crisis spell) and the coerciveness index (as yearly averages over each crisis spell).

\subsection{Default coding and sample composition}

Our analysis spans the years between 1980 and 2009 and includes 61 developing and emerging market economies. We selected this sample as follows. Given our focus on debt crises involving commercial creditors, we first excluded those countries which had only very limited access to foreign private credit over our sample period. Specifically, we drop all countries that have been classified by the IMF and the World Bank as highly indebted poor countries (HIPCs) and typically owe more than $80 \%$ of their external debt to official (not private) creditors. We also drop small countries with a population of less than 1 million (as measured at the end of our sample period) and exclude all advanced economies in order to make our sample as homogeneous as possible. Moreover, we drop a few defaulters for which no sufficient qualitative information on the debt renegotiation process and on debt payments was available (Côte d'Ivoire, 
Cuba, Gabon, Iran, Jamaica, Kenya, Paraguay, Trinidad and Tobago and Vietnam) and countries whose debt restructurings took place in the context of wars and state dissolution, namely Iraq and the successor states of the Socialist Republic of Yugoslavia. The resulting set of 61 countries includes 25 defaulting countries, which experienced at least one debt crisis during our sample period, as well as a 36 non-defaulters. Table A.1 in the Online Appendix shows all countries and years, including a list of debt crisis episodes studied here.

To measure sovereign defaults, we follow the widely used default definition of Standard \& Poor's and rely on their annual default list. S\&P codes a government as being in default if the government misses payments on either interest or principal of bonds or bank loans on the due date or, alternatively, if it announces a debt exchange offer that leads to less favorable conditions for creditors than those in the original contracts (see Appendix 1 of Standard \& Poor's, 2011). All in all, our sample covers 1,638 annual country observations, of which 210 observations are default years.

\section{Output performance during default}

\subsection{Preliminary analysis and stylized facts}

We start our analysis of growth during debt crises with a graphical view at the data. Figure 4 illustrates the performance of real GDP per capita from three years before until five years after start of default. The starting year of a crisis is labeled as year zero (black vertical line) and GDP is normalized to 100 in the year prior to the start of the debt crisis, as defined above.

Panel A depicts the average GDP performance for the 31 debt crises in our sample. ${ }^{12}$ In line with Levy-Yeyati and Panizza (2011), we find that the onset of a debt crisis roughly marks the beginning of recovery. On average, GDP starts to decline prior to a debt crisis and shrinks by another four percent in the year of default. Immediately after, however, output starts to recover and reaches its pre-crisis level four years later.

In Panel B of Figure 4, we divide the sample into cases of hard and soft defaults. For this purpose, we compute the average value of the coerciveness index over each

\footnotetext{
${ }^{12}$ This number is larger than the number of defaulting countries (25) due to the fact that some countries defaulted multiple times (see Table A.1 in the Online Appendix). Note also that we drop follow-up defaults that are very close in timing and thus effectively in the same crisis spell, i.e. those that occur in the time window [-3,+5]. Specifically, we exclude Romania 1985, Morocco 1986, Uruguay 1987 and 1990, South Africa 1989, and Venezuela 1990.
} 
Figure 4: Real GDP around the start of default

(a) Panel A: All defaults

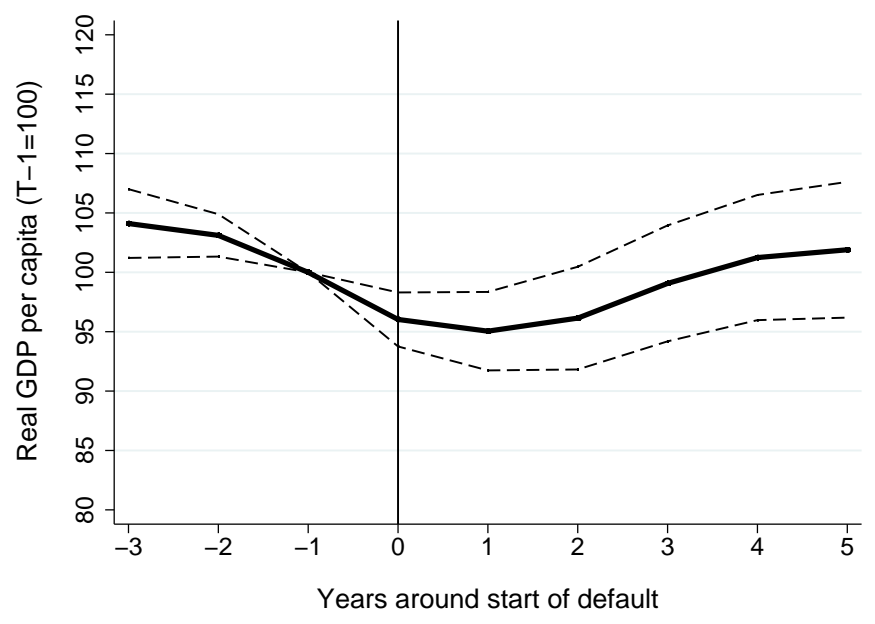

(b) Panel B: Hard and soft defaults

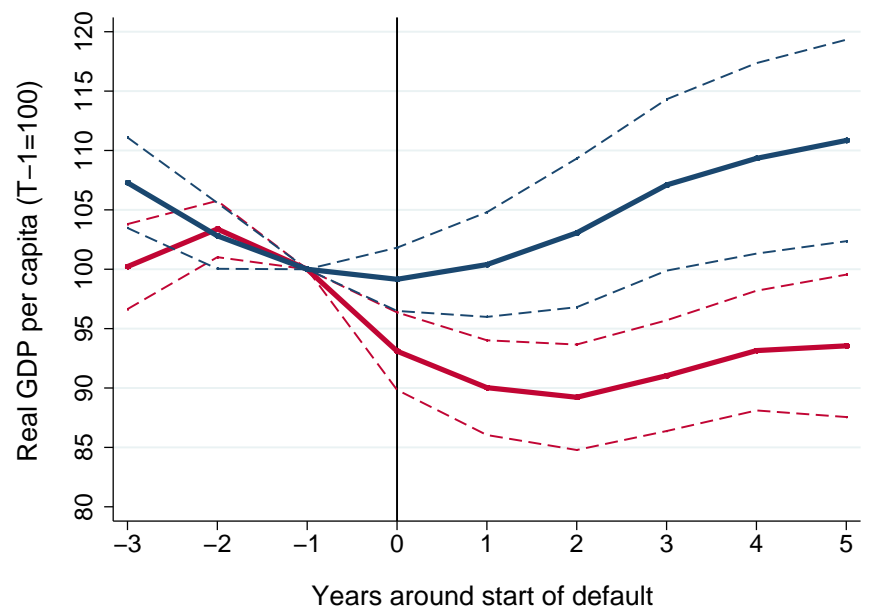

Note: The solid lines show average real GDP per capita from three years before until five years after the start of default. The dashed lines are $90 \%$ confidence intervals. Real GDP per capita is normalized to 100 in the year before the start of default. Panel A includes the full sample of default episodes, while Panel B splits the sample at the median average coerciveness across crisis episodes, which is 3.4. Cases of soft default are shown in red (coerciveness values larger than 3.4) while soft defaults are shown in blue (average coerciveness smaller than 3.4).

debt crisis and cut the sample at the median value, which is 3.4. The result are 15 cases categorized as soft defaults (with an average government coerciveness index of less than 3.4) and 16 cases of hard default (with average coerciveness larger than 3.4). 
As can be seen, output behaves very differently for both groups. In soft default spells, output drops only marginally in the first crisis year and quickly picks up afterwards. However, the picture drastically differs for hard defaults, with an output collapse of around seven percent in the first crisis year and a further decline during the subsequent year. Thereafter, the economy recovers only sluggishly. Five years after the outbreak of the crisis, real GDP remains more than five percentage points below its pre-crisis level. The result of quick recoveries by Levy-Yeyati and Panizza (2011) can thus not be confirmed for hard defaults, since these cases do not see a rebound after the first default year. The difference in real GDP performance between hard and soft defaulters is statistically significant at the $10 \%$ level.

\subsection{Regression analysis}

In this subsection, we analyze the relationship between debtor coerciveness and GDP in a more systematic way. Our main empirical model looks as follows:

$$
\operatorname{Growth}_{i, t}=\alpha_{i}+\alpha_{t}+\beta \text { Default } \text { fat, }+\gamma \operatorname{Coerc}_{i, t}+\delta X_{i, t}+\epsilon_{i, t},
$$

where Growt $_{i, t}$ is the annual real per capita GDP growth rate, $\operatorname{Coerc}_{i, t}$ is the time varying coerciveness index measured in each debt crisis year, Default $t_{i, t}$ is a binary variable capturing sovereign defaults according to S\&P (defined as 1 in years with missed payments or debt restructuring and 0 otherwise), $X_{i, t}$ is a vector for our set of macroeconomic controls, and $\alpha_{i}$ and $\alpha_{t}$ stand for country and time fixed effects, respectively.

Formally, equation 1 is a multiplicative interaction model in which we interact the default dummy with the coerciveness index, which is only coded during default spells. $\gamma$ should thus be interpreted as the coefficient of an interaction term, since the coerciveness index is always 0 in non-crisis years and its value in crisis years is equal to multiplying the default dummy with the index of coerciveness. The sum $\beta+\gamma \operatorname{Coerc}_{i, t}$ will thus pick up the joint effect of a default and coerciveness on growth. Intuitively, this allows us to assess the correlation of default and growth, conditional on the scope of debtor coerciveness during the default.

To assure that the model is properly identified, the constitutive term De fault $_{i, t}$ has to be included in all specifications and its coefficient can no longer be interpreted at face value whenever the interacted variable $\operatorname{Coerc}_{i, t}$ is also included. In this econometric

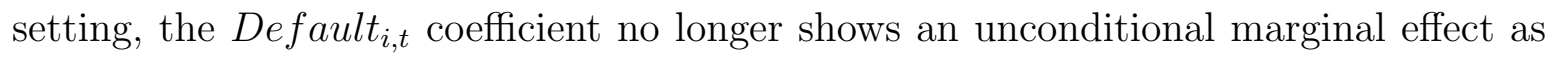
in a standard multivariate regression (see Brambor et al., 2006). The high correlation 
between Default $t_{i, t}$ and $\operatorname{Coerc}_{i, t}$ is likely to increase the estimated standard errors (see Goldberger, 1991, chapter 23). This is a relevant concern, but it also stacks the odds against us, since we are more likely to find insignificant coefficients for $\operatorname{Coerc}_{i, t}$. Moreover, Kennedy (2003) and (Goldberger, 1991) explain that multicollinearity can actually be desirable if one is interested in the joint effect of two highly correlated variables, which is the case here. Indeed, multicollinearity in our context will tend to lower the variance of the estimated effect of interest, $\beta+\gamma \operatorname{Coerc}_{i, t}$.

Before estimating our main model, we start with a bare bones specification in Column 1 , in which we regress the annual real GDP growth per capita $\left(\right.$ Growth $\left._{i, t}\right)$ on a dummy variable capturing whether a country is in default $\left(\right.$ Default $\left._{i, t}\right)$ and on a set of year dummies to control for global (i.e. not country-specific) time trends using pooled OLS. In line with previous research, the default dummy turns out highly significant and negative (Table 1, Column 1). The coefficient value of around -1.1 indicates that being in a debt crisis reduces a country's GDP growth by around $1.1 \%$ per year.

In model 2, we include both the binary default dummy and $\operatorname{Coer}_{i, t}$. As can be seen, the coerciveness index turns out highly significant with a large negative coefficient. A one notch increase in the index is associated with 0.6 percentage point lower real GDP growth for each crisis year. We next add a set of macro controls $\left(X_{i, t}\right)$ that is commonly used in the cost of default literature (Sturzenegger, 2004; Borensztein and Panizza, 2009; Levy-Yeyati and Panizza, 2011). Specifically, we include investment to GDP (InvGDP), rate of population growth $(\triangle P o p)$, log of total population $(\log (P o p))$, percentage of the population that completed secondary education $(S e c E d u)$, lagged annual growth of government consumption (GovtCons $s_{t-1}$ ), the Freedom House index of civil liberties (CivLib), annual change in terms-of-trade $(\Delta T o T)$, openness, as proxied by the ratio of imports plus exports to GDP (Openness), and a dummy variable for banking crises (BankingCrisis). Table A.2 in the Online Appendix provides a detailed description of each control variable and its source.

Column 3 shows that the coefficient and significance of the default dummy barely changes when adding the set of growth controls. Moreover, the results and the estimated default coefficient are almost identical to previous studies on the cost of default such as Panizza et al. (2009) and Sturzenegger (2004). ${ }^{13}$ Column 4 shows that the coerciveness

\footnotetext{
${ }^{13}$ Panizza et al. (2009) estimate a default dummy coefficient of -1.3 , compared to -1.1 in Column 3 . We also get a result very similar to Sturzenegger (2004), once we replace the default dummy (for each year during default) with a dummy variable that only captures the first and the second year of a debt crisis. Debt crises can then be associated with a decline in GDP growth of around $2 \%$ during the first two years of default.
} 
Table 1: GDP growth and government coerciveness during default

\begin{tabular}{|c|c|c|c|c|c|c|c|c|}
\hline & $\begin{array}{c}(1) \\
\text { Plain }\end{array}$ & $\begin{array}{c}(2) \\
\text { Plain }\end{array}$ & $\begin{array}{c}(3) \\
\text { With } \\
\text { controls }\end{array}$ & $\begin{array}{c}(4) \\
\text { With } \\
\text { controls }\end{array}$ & $\begin{array}{c}(5) \\
\text { Average } \\
\text { Coerc }\end{array}$ & $\begin{array}{c}(6) \\
\text { Coerc vs. } \\
\text { AvgCoerc }\end{array}$ & $\begin{array}{c}(7) \\
\text { Main } \\
\text { model }\end{array}$ & $\begin{array}{c}(8) \\
\text { With } \\
\text { Haircuts }\end{array}$ \\
\hline Default & $-1.140^{* *}$ & 1.134 & $-1.099 * *$ & 0.370 & 0.428 & 1.827 & 1.129 & 0.325 \\
\hline (Dummy) & $(0.468)$ & $(0.713)$ & $(0.442)$ & $(0.751)$ & $(0.959)$ & $(1.328)$ & $(1.006)$ & $(0.829)$ \\
\hline Coerc & & $-0.627 * * *$ & & $-0.422^{* *}$ & & $-0.414^{*}$ & $-0.566^{* *}$ & \\
\hline (Index) & & $(0.192)$ & & $(0.202)$ & & $(0.246)$ & $(0.221)$ & \\
\hline Average & & & & & $-0.433^{*}$ & -0.358 & & \\
\hline Coerc & & & & & $(0.262)$ & $(0.345)$ & & \\
\hline $\begin{array}{l}\text { Haircuts } \\
\text { (expected) }\end{array}$ & & & & & & & & $\begin{array}{c}-0.035^{*} \\
(0.020)\end{array}$ \\
\hline $\operatorname{Inv} / G D P$ & & & $\begin{array}{c}17.683^{* * *} \\
(2.077)\end{array}$ & $\begin{array}{c}17.588^{* * *} \\
(2.057)\end{array}$ & $\begin{array}{c}17.699^{* * *} \\
(2.074)\end{array}$ & $\begin{array}{c}17.792^{* * *} \\
(3.492)\end{array}$ & $\begin{array}{c}17.637^{* * *} \\
(3.497)\end{array}$ & $\begin{array}{c}18.044^{* * * *} \\
(2.078)\end{array}$ \\
\hline$\triangle P o p$ & & & $\begin{array}{c}-0.339^{* *} \\
(0.144)\end{array}$ & $\begin{array}{c}-0.319^{* *} \\
(0.142)\end{array}$ & $\begin{array}{c}-0.315^{* *} \\
(0.143)\end{array}$ & $\begin{array}{l}-0.074 \\
(0.344)\end{array}$ & $\begin{array}{l}-0.087 \\
(0.345)\end{array}$ & $\begin{array}{c}-0.328^{* *} \\
(0.144)\end{array}$ \\
\hline $\log ($ Pop $)$ & & & $\begin{array}{l}-0.093 \\
(0.090)\end{array}$ & $\begin{array}{l}-0.084 \\
(0.089)\end{array}$ & $\begin{array}{l}-0.087 \\
(0.090)\end{array}$ & $\begin{array}{l}-3.398 \\
(3.776)\end{array}$ & $\begin{array}{l}-3.491 \\
(3.783)\end{array}$ & $\begin{array}{l}-0.111 \\
(0.091)\end{array}$ \\
\hline$S e c E d u$ & & & $\begin{array}{c}0.008 \\
(0.010)\end{array}$ & $\begin{array}{c}0.009 \\
(0.010)\end{array}$ & $\begin{array}{c}0.009 \\
(0.010)\end{array}$ & $\begin{array}{l}-0.004 \\
(0.035)\end{array}$ & $\begin{array}{l}-0.004 \\
(0.035)\end{array}$ & $\begin{array}{c}0.009 \\
(0.010)\end{array}$ \\
\hline GovtCons $_{t-1}$ & & & $\begin{array}{c}0.112^{* * * *} \\
(0.020)\end{array}$ & $\begin{array}{c}0.112^{* * * *} \\
(0.020)\end{array}$ & $\begin{array}{c}0.112^{* * * *} \\
(0.020)\end{array}$ & $\begin{array}{c}0.089 * * * \\
(0.018)\end{array}$ & $\begin{array}{c}0.088^{* * * *} \\
(0.018)\end{array}$ & $\begin{array}{c}0.110^{* * * *} \\
(0.020)\end{array}$ \\
\hline CivLib & & & $\begin{array}{l}-0.092 \\
(0.091)\end{array}$ & $\begin{array}{l}-0.104 \\
(0.090)\end{array}$ & $\begin{array}{l}-0.112 \\
(0.091)\end{array}$ & $\begin{array}{l}-0.053 \\
(0.217)\end{array}$ & $\begin{array}{l}-0.021 \\
(0.218)\end{array}$ & $\begin{array}{l}-0.108 \\
(0.091)\end{array}$ \\
\hline$\Delta T o T$ & & & $\begin{array}{c}10.364^{* * *} \\
(1.220)\end{array}$ & $\begin{array}{c}10.240^{* * *} \\
(1.203)\end{array}$ & $\begin{array}{c}10.375^{* * * *} \\
(1.209)\end{array}$ & $\begin{array}{c}9.903^{* * *} \\
(1.356)\end{array}$ & $\begin{array}{c}9.838^{* * *} \\
(1.351)\end{array}$ & $\begin{array}{c}10.475^{* * * *} \\
(1.207)\end{array}$ \\
\hline Openness & & & $\begin{array}{l}-0.003 \\
(0.002)\end{array}$ & $\begin{array}{l}-0.002 \\
(0.002)\end{array}$ & $\begin{array}{l}-0.003 \\
(0.002)\end{array}$ & $\begin{array}{l}-0.007 \\
(0.014)\end{array}$ & $\begin{array}{l}-0.007 \\
(0.014)\end{array}$ & $\begin{array}{l}-0.003 \\
(0.002)\end{array}$ \\
\hline $\begin{array}{l}\text { BankingCrisis } \\
\text { (Dummy) }\end{array}$ & & & $\begin{array}{c}-2.533^{* * *} \\
(0.820)\end{array}$ & $\begin{array}{c}-2.422^{* * * *} \\
(0.815)\end{array}$ & $\begin{array}{c}-2.470^{* * *} \\
(0.810)\end{array}$ & $\begin{array}{c}-2.175^{* *} \\
(0.842)\end{array}$ & $\begin{array}{c}-2.185^{* *} \\
(0.850)\end{array}$ & $\begin{array}{c}-2.471^{* * * *} \\
(0.820)\end{array}$ \\
\hline Observations & 1,638 & 1,638 & 1,113 & 1,113 & 1,113 & 1,113 & 1,113 & 1,113 \\
\hline Countries & 61 & 61 & 45 & 45 & 45 & 45 & 45 & 45 \\
\hline Time FE & YES & YES & YES & YES & YES & YES & YES & YES \\
\hline Country FE & $\mathrm{NO}$ & $\mathrm{NO}$ & NO & $\mathrm{NO}$ & NO & YES & YES & NO \\
\hline$R^{2}$ & 0.129 & 0.135 & 0.354 & 0.359 & 0.357 & 0.322 & 0.321 & 0.357 \\
\hline
\end{tabular}

Note: The dependent variable is the annual growth rate of real GDP per capita, measured in percentage points. The key explanatory variable is the coerciveness index, Coerc, but we also use the average coerciveness index over a debt crisis, as well as the (expected) haircut size, using the same haircut value for each crisis year until the final restructuring. All specifications include a (non-reported) constant. Robust standard errors are given in parentheses. ${ }^{* * *},{ }^{* *}$, and ${ }^{*}$ denote significance at the 1,5 , and 10 per cent levels, respectively.

index remains significant when including this same set of macro controls, although the coefficient size drops slightly, from -0.63 in the bare-bones model to -0.42 .

In a next step, we distinguish between average coerciveness across crises and timevarying coerciveness within the same crisis. Our motivation of doing so is that the pooled OLS results mask where the explanatory power of $\operatorname{Coerc}_{i, t}$ stems from. Given the annual coding, the significant coefficient could result (i) from variation in the coerciveness index across different default episodes, or (ii) from variation in the coerciveness index within default episodes, or (iii) from both. 
The results in Column 5 of Table 1 indicate that the differences in the level of debtor coerciveness across crises play an important role. Average Coerc is defined as the mean of the annual coerciveness observations observed in each debt crisis episode, so that this measure varies across but not within debt crises. The resulting coefficient of -0.43 and is significant at the $10 \%$ level. This finding underlines our previous descriptive insight that debt crises with more coercive average payment and negotiation patterns are associated with substantially weaker GDP growth (Figure 4).

Furthermore, in Column 6 we aim to distill the role of within-crisis variation in the coerciveness index. For this purpose, we estimate a panel model with country fixed effects and then run a horse race between Average Coerc and the time varying coerciveness index Coerc. While the fixed effects absorb the cross-country variation in debtor coerciveness, adding Average Coerc accounts for the fact that some countries in our sample defaulted multiple times. This implies that the coefficient of Coerc will now solely pick up the variation in debtor coerciveness within the same debt crisis. As can be seen, Coerc is significant at the $10 \%$ level with a quantitatively large coefficient, which supports the view that also the within-crisis variation matters for our main result. Overall, we thus conclude that the coerciveness index helps to explain output growth both within and across debt crisis events.

We move on to estimate our main model of equation (1). The results are shown in Column 7 . The only difference to Column 4 is that we now include country fixed effects, which pick up time-invariant country-specific characteristics. This is important since it allows us to account for differences in the strength of institutions or any other source of unobserved heterogeneity that could drive both the level of government coerciveness and output performance during crises. Because we drop AvgCoerc, the coerciveness index now captures both the time variation within debt crises as well as the variation between crises in the same country. The resulting coefficient of -0.57 implies that a one-notch increase in the coerciveness index is associated with a 0.57 percentage point lower growth in that country. Put differently, moving from a coerciveness index level of 1 (Dominican Republic in 2005) to a level of 7 (Dominican Republic in 1990) is associated with a 3 percentage point lower growth rate in each default year, after controlling for standard macroeconomic controls, global trends, and the default effect per se. Given that the average debt crisis takes more than five years to resolve, the cumulative growth differences are very large.

Maybe the best way to illustrate our main finding is the interaction graph of Figure 5, which shows real GDP growth in default spells, conditional on the level of government 
Figure 5: Real GDP growth during default conditional on debtor coerciveness

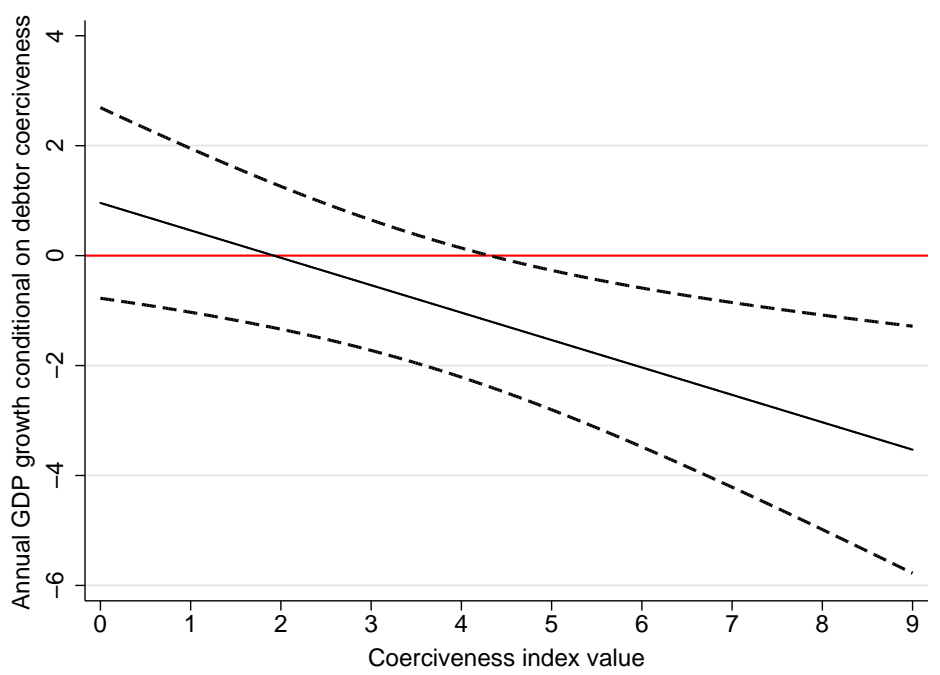

Note: This figure shows the estimated output loss during default for different levels in the debtor coerciveness index. The vertical axis plots the joint estimate $\beta+\gamma \operatorname{Coerc}_{i, t}$ based on our baseline specification (7) of Table 1 . The dotted lines are 90 percent confidence bands. The main message of this graph is that defaults are only associated with lower growth if the coerciveness index values is 4 or higher (where the upper confidence band exceeds the zero horizontal line). Soft defaults with few coercive actions towards creditors see no significant growth decline.

coerciveness (using the fully specified model of Column 7). The vertical axis shows $\beta+\gamma \operatorname{Coerc}_{i, t}$, i.e. the expected growth impact of a default for different levels in the debtor coerciveness index, while the dotted lines show 90 percent confidence bands. The bottom line of the figure is that defaults are only associated with significantly lower growth if governments adopt at least a medium level of coerciveness towards their foreign creditors. This is because the upper confidence band is above the 0 horizontal line only for index values above 4 . This is slightly higher than the sample mean coerciveness of 3.6. At an index value of 7 , the estimated joint effect of a coercive default is large, indicating three percentage points lower growth each year. In contrast, soft defaults with index values of 1 or 2 do not see a significant decline in growth compared to normal times.

In a complementary step, we now replace the coerciveness index in equation (1) with the size of haircuts measured at the end of a default spell. Specifically, we take the estimated haircut and use its value for each crisis year in the run up to the final restructuring. The resulting variable can be interpreted as the expected size of haircuts, but should be taken with care given that the debt crises often span more than 10 years. It is unrealistic that markets correctly anticipate the haircut imposed 10 or 15 years 
later. Moreover, haircuts tend to be higher in protracted defaults, as documented by Benjamin and Wright (2009). ${ }^{14}$ The haircut measure used in this specification is therefore closest to the AvgCoerc measure of Column 5. Indeed, the pairwise correlation between those two is $70 \%$, as shown in Figure 3.

Column 8 shows that the haircut variable has a negative coefficient of -0.035 and is significant at the $10 \%$ level. This suggests that increasing the haircut by 10 percentage points is associated with a reduction in annual GDP growth of $0.35 \%$ during defaults. Put differently, a shift from a haircut of $10 \%$ (as in Uruguay 2003) to a haircut of $77 \%$ (as in Argentina 2005) is associated with 2.5\% lower growth.

\subsection{Robustness checks}

This section addresses additional identification challenges and tests the robustness of our main model of eq. (1).

Autocorrelated standard errors: It is possible that the regression residuals are serially correlated, in particular since past growth rates are known to be a good predictor of contemporaneous and future growth. Autocorrelation in the error terms would bias the estimated standard errors downwards and thus overestimate the t-statistics (Cameron and Tivedi, 2005). One way to address this problem, is to add a lagged value of our dependent variable $\left(\right.$ Growth $\left._{i, t-1}\right)$, which we do in Column 1 of Table 2. As can be seen, the results remain largely unaltered and the coerciveness index continues to be strongly significant and negative.

While including lagged GDP growth as an explanatory variable solves the problem of autocorrelated error terms in our model, this step can also introduce bias, as famously pointed out by Hurwicz (1950) and Nickell (1981). The fixed effects center all variables by country which induces a correlation between the centered lagged dependent variable on the one hand and the centred error term on the other. This "Nickell bias" is of order $1 / T$, such that it decreases with rising $T$ but is very serious for panels with a short time horizon. A sample of $\mathrm{T}=30$, as it is the case here, may still result in a bias of up to $20 \%$ of the true coefficient value, as shown by (Judson and Owen, 1999). In order to correct for the "Nickell bias", we follow Beck and Katz (2011) and Judson and Owen (1999) and move back to a simple OLS framework (without country fixed effects). Column 2 shows that our results continue to hold, although the coerciveness index decreases in size and remains significant only at the $10 \%$ level. Another approach

\footnotetext{
${ }^{14}$ The link between default duration and debtor coerciveness is discussed in the robustness section.
} 
to tackle the Nickell bias is to run a GMM estimation. ${ }^{15}$ Column 3 shows the result: the coerciveness index remains significant, with a coefficient that is similar to our main specification. We therefore conclude that our baseline estimation results are robust even after accounting for the possibility of serially correlated errors.

Controlling for crisis duration: One important fact about debt crises is that they vary greatly in length. For example, the debt crises of South Africa 1993 and Uruguay 2003 could be resolved in a few months, while the defaults of Argentina, Brazil or Panama of the early 1980s took more than 10 years from start to end. If debtor coerciveness is correlated with the duration of a debt crisis, this could bias our estimation results. However, the descriptive statistics do not suggest a close correlation of these two variables (the correlation is just 0.14). Moreover, changes in debtor coerciveness do not exhibit significant trend patterns over the course of a crisis, as shown in Figure A.3 in the Online Appendix, so the coerciveness index is more or less uniformly distributed across the length of a debt crisis. Despite this, we extend our regression to explicitly control for crisis duration in Column 4 of Table $2 .^{16}$ The results remain stable, suggesting that crisis duration does not bias our estimation results in a significant way.

Additional controls: IMF programs, political risk, government changes and further macro variables: While we control for time-invariant country characteristics, global trends, and standard macro controls, our estimation results could still be biased due to the omission of time-varying country-specific variables correlated with both the government payment and negotiation behavior and growth. One such potential confounder is the involvement of the IMF, since IMF loans can be used to repay debt coming due and because the IMF typically demands governments to adopt a cooperative stance towards external creditors. In Column 5 of Table 2 we therefore show a specification that adds a binary variable for ongoing IMF programs taken from the database compiled by Reinhart and Trebesch (2016b). The lagged IMF program dummy is significant with a large positive coefficient, but including it does not alter our main findings.

Another potential confounder is political risk, since debtor coerciveness may increase during times of political turmoil or when new governments take over. We therefore add the widely used ICRG political risk indicator as a control variable, which ranges from 0 (very high political risk) to 100 (very low political risk), as well as a dummy for changes

\footnotetext{
${ }^{15}$ We thank a referee for making this suggestion.

${ }^{16}$ More technically, we add dummy variables that take on the value of one during each year in which the respective country has been at least $i$ years in default (for $i \in\{1 ; 15\}$ ). This approach should provide a clean identification of the effects of crisis duration and avoids ad hoc assumptions on the functional form of how crisis duration affects GDP growth.
} 
Table 2: Robustness checks for GDP growth and coerciveness

\begin{tabular}{|c|c|c|c|c|c|c|c|}
\hline & $\begin{array}{c}(1) \\
\text { Lagged } \\
\text { growth }\end{array}$ & $\begin{array}{c}(2) \\
\text { OLS lagged } \\
\text { growth }\end{array}$ & $\begin{array}{l}(3) \\
\text { GMM } \\
\text { model }\end{array}$ & $\begin{array}{c}(4) \\
\text { With crisis } \\
\text { Duration }\end{array}$ & $\begin{array}{c}(5) \\
\text { With IMF } \\
\text { programs }\end{array}$ & $\begin{array}{c}\text { (6) } \\
\text { Additional } \\
\text { Controls }\end{array}$ & $\begin{array}{c}(7) \\
\text { Ctr-spec. } \\
\text { time-trend }\end{array}$ \\
\hline $\begin{array}{l}\text { Default } \\
\text { (Dummy) }\end{array}$ & $\begin{array}{c}1.433 \\
(0.988)\end{array}$ & $\begin{array}{c}0.916 \\
(0.768)\end{array}$ & $\begin{array}{c}1.844 \\
(1.278)\end{array}$ & $\begin{array}{c}1.357 \\
(1.714)\end{array}$ & $\begin{array}{c}0.578 \\
(0.987)\end{array}$ & $\begin{array}{c}0.320 \\
(0.748)\end{array}$ & $\begin{array}{c}0.206 \\
(0.906)\end{array}$ \\
\hline Coerc & $\begin{array}{c}-0.477^{* *} \\
(0.206)\end{array}$ & $\begin{array}{c}-0.360^{*} \\
(0.200)\end{array}$ & $\begin{array}{c}-0.480^{*} \\
(0.266)\end{array}$ & $\begin{array}{c}-0.614^{* * *} \\
(0.201)\end{array}$ & $\begin{array}{c}-0.495^{* *} \\
(0.229)\end{array}$ & $\begin{array}{c}-0.503^{* * *} \\
(0.188)\end{array}$ & $\begin{array}{c}-0.537^{* * *} \\
(0.192)\end{array}$ \\
\hline Growth $_{t-1}$ & $\begin{array}{c}0.264^{* * *} \\
(0.067)\end{array}$ & $\begin{array}{c}0.329^{* * *} \\
(0.047)\end{array}$ & $\begin{array}{c}0.289^{* * * *} \\
(0.071)\end{array}$ & & & & \\
\hline $\begin{array}{l}I M F_{t-1} \\
\text { (Dummy) }\end{array}$ & & & & & $\begin{array}{c}1.441^{* * *} \\
(0.411)\end{array}$ & & \\
\hline $\operatorname{Inv} / G D P$ & $\begin{array}{c}11.287^{* * *} \\
(3.765)\end{array}$ & $\begin{array}{c}10.576^{* * *} \\
(2.268)\end{array}$ & $\begin{array}{c}19.996^{* * *} \\
(5.108)\end{array}$ & $\begin{array}{c}17.680^{* * *} \\
(3.394)\end{array}$ & $\begin{array}{c}19.011^{* * *} \\
(3.506)\end{array}$ & $\begin{array}{c}23.248^{* * *} \\
(3.601)\end{array}$ & $\begin{array}{c}33.512^{* * *} \\
(5.673)\end{array}$ \\
\hline$\triangle P o p$ & $\begin{array}{c}-0.193 \\
(0.306)\end{array}$ & $\begin{array}{c}-0.318^{* *} \\
(0.137)\end{array}$ & $\begin{array}{c}-0.968^{* * *} \\
(0.285)\end{array}$ & $\begin{array}{c}-0.119 \\
(0.355)\end{array}$ & $\begin{array}{c}-0.104 \\
(0.354)\end{array}$ & $\begin{array}{c}-0.975 * * * \\
(0.342)\end{array}$ & $\begin{array}{c}-0.541 \\
(0.354)\end{array}$ \\
\hline $\log ($ Pop $)$ & $\begin{array}{l}-1.187 \\
(2.513)\end{array}$ & $\begin{array}{c}-0.049 \\
(0.083)\end{array}$ & $\begin{array}{c}-1.900 \\
(2.833)\end{array}$ & $\begin{array}{l}-3.502 \\
(3.622)\end{array}$ & $\begin{array}{l}-3.629 \\
(3.597)\end{array}$ & $\begin{array}{c}4.193 \\
(2.760)\end{array}$ & $\begin{array}{c}-56.095^{* * *} \\
(15.626)\end{array}$ \\
\hline$S e c E d u$ & $\begin{array}{c}-0.008 \\
(0.028)\end{array}$ & $\begin{array}{c}0.001 \\
(0.009)\end{array}$ & $\begin{array}{l}0.098^{*} \\
(0.058)\end{array}$ & $\begin{array}{l}-0.007 \\
(0.034)\end{array}$ & $\begin{array}{c}0.004 \\
(0.036)\end{array}$ & $\begin{array}{c}-0.004 \\
(0.032)\end{array}$ & $\begin{array}{c}0.052 \\
(0.072)\end{array}$ \\
\hline GovtCons $_{t-1}$ & $\begin{array}{c}0.051^{* * *} \\
(0.018)\end{array}$ & $\begin{array}{c}0.057 * * * \\
(0.022)\end{array}$ & $\begin{array}{c}0.023 \\
(0.026)\end{array}$ & $\begin{array}{c}0.093^{* * *} \\
(0.018)\end{array}$ & $\begin{array}{c}0.090^{* * *} \\
(0.018)\end{array}$ & $\begin{array}{c}0.080^{* * *} * \\
(0.024)\end{array}$ & $\begin{array}{c}0.072^{* * * *} \\
(0.026)\end{array}$ \\
\hline CivLib & $\begin{array}{c}-0.071 \\
(0.166)\end{array}$ & $\begin{array}{l}-0.052 \\
(0.087)\end{array}$ & $\begin{array}{c}0.047 \\
(0.329)\end{array}$ & $\begin{array}{c}-0.009 \\
(0.203)\end{array}$ & $\begin{array}{c}0.042 \\
(0.225)\end{array}$ & $\begin{array}{l}-0.072 \\
(0.225)\end{array}$ & $\begin{array}{c}-0.418 \\
(0.283)\end{array}$ \\
\hline$\Delta T o T$ & $\begin{array}{c}9.081^{* * *} \\
(1.148)\end{array}$ & $\begin{array}{c}9.122^{* * *} \\
(1.113)\end{array}$ & $\begin{array}{c}7.679^{* * *} \\
(1.123)\end{array}$ & $\begin{array}{c}9.868^{* * *} \\
(1.275)\end{array}$ & $\begin{array}{c}9.868^{* * *} \\
(1.338)\end{array}$ & $\begin{array}{c}8.660^{* * *} \\
(1.118)\end{array}$ & $\begin{array}{c}8.445^{* * *} \\
(1.189)\end{array}$ \\
\hline Openness & $\begin{array}{c}-0.006 \\
(0.011)\end{array}$ & $\begin{array}{c}-0.001 \\
(0.002)\end{array}$ & $\begin{array}{l}-0.022 \\
(0.015)\end{array}$ & $\begin{array}{l}-0.009 \\
(0.014)\end{array}$ & $\begin{array}{c}-0.005 \\
(0.014)\end{array}$ & $\begin{array}{c}0.027^{* * *} \\
(0.009)\end{array}$ & $\begin{array}{c}0.010 \\
(0.014)\end{array}$ \\
\hline $\begin{array}{l}\text { BankingCrisis } \\
\text { (Dummy) } \\
\text { Political Risk }\end{array}$ & $\begin{array}{c}-2.414^{* * *} \\
(0.805)\end{array}$ & $\begin{array}{c}-2.630^{* * *} \\
(0.753)\end{array}$ & $\begin{array}{c}-2.004^{* *} \\
(0.815)\end{array}$ & $\begin{array}{c}-1.719^{* *} \\
(0.776)\end{array}$ & $\begin{array}{c}-2.189 * * \\
(0.860)\end{array}$ & $\begin{array}{c}-2.966 * * * \\
(0.841) \\
0.038 \\
(0.026)\end{array}$ & $\begin{array}{c}-3.051^{* * *} \\
(0.820) \\
0.018 \\
(0.036)\end{array}$ \\
\hline $\begin{array}{l}\text { GovChange } \\
\text { (Dummy) } \\
\text { CurrencyCrisis } \\
\text { (Dummy) } \\
\text { DebtGDP }\end{array}$ & & & & & & $\begin{array}{c}-0.573^{*} \\
(0.346) \\
-4.866^{* * *} \\
(0.936) \\
0.032^{* * *} \\
(0.011)\end{array}$ & $\begin{array}{c}-0.629^{*} \\
(0.370) \\
-5.055^{* * *} \\
(1.038) \\
0.078^{* *} \\
(0.031)\end{array}$ \\
\hline Observations & 1,113 & 1,113 & 1,068 & 1,113 & 1,113 & 866 & 866 \\
\hline Countries & 45 & 45 & 45 & 45 & 45 & 43 & 43 \\
\hline Time FE & YES & YES & YES & YES & YES & YES & YES \\
\hline Country FE & YES & $\mathrm{NO}$ & YES & YES & YES & YES & YES \\
\hline Duration Controls & NO & $\mathrm{NO}$ & $\mathrm{NO}$ & YES & $\mathrm{NO}$ & NO & $\mathrm{NO}$ \\
\hline Ctry-spc. t-trend & NO & NO & $\mathrm{NO}$ & NO & NO & NO & YES \\
\hline$R^{2}$ & 0.370 & 0.433 & & 0.346 & 0.336 & 0.397 & 0.388 \\
\hline
\end{tabular}

Note: The dependent variable is the annual growth rate of real GDP per capita, measured in percentage points. The key explanatory variable is the coerciveness index, Coerc. All specifications include a (nonreported) constant. Robust standard errors are given in parentheses. ${ }^{* * *},{ }^{* *}$, and ${ }^{*}$ denote significance at the 1,5 , and 10 per cent levels, respectively.

in the executive, with data taken from the Database of Political Institutions (DPI). Furthermore, we control for the occurrence of currency crises (CurrencyCrisis) using data from from Laeven and Valencia (2012) and for the debt to GDP ratio (DebtGDP) from Abbas et al. (2010). Since DebtGDP might expose our estimation to endogeneity, we instrument that variable by its first two lags. The results in Column 6 of Table 2 show that our baseline estimation results are by and large unchanged when adding 
these additional controls. The coerciveness index retains its significant and negative coefficient. Moreover, in Column 7, we add country-specific time trends, with results being stable. In a last step, we also tested for non-linear effects, by adding a quadratic term of the coerciveness index to our main models. However, this additional control was clearly insignificant and did not improve the model fit (not shown).

\subsection{Reverse causality and expected vs. unexpected coercive- ness}

It is possible that the observed negative correlation between coerciveness and GDP growth is due to reverse causality. A steep decline in GDP can erode a country's tax base and foreign exchange revenues, thus affecting the government's ability to repay and its renegotiations with external creditors. To address this possibility, we test whether lagged values of real GDP per capita growth can predict current debtor coerciveness. Columns 1-3 of Table 3 show that the coefficients of lagged GDP growth are clearly insignificant at different lag lengths, suggesting that past growth performance does not significantly affect the government's subsequent debt policies. Of course, this does not preclude the possibility of a contemporaneous causal effect of real growth on debtor coerciveness. But the results provide some assurance that reverse causality is not the main channel behind our findings.

To shed further light on the channel at work, we try to isolate the impact of changes in debtor coerciveness from potential expectation effects. This is in line with Borensztein and Panizza (2009) and Panizza et al. (2009), who argue that the drop in output at the start of debt crises could (to some extent) be driven by investor expectations about a country's default rather than by the default event per se. We therefore explore whether the observed output contraction can mostly be explained by unexpected coercive actions of the government ("surprise coerciveness") or rather by coercive actions that were anticipated.

To disentangle expected and unexpected coerciveness, we resort to a strategy similar to Barro (1977) and Borensztein and Panizza (2009). It consists in dividing the coerciveness index into an anticipated and an unanticipated component and then to test the marginal influence of both components on GDP growth. To this end, we first regress a country's coerciveness on the country's credit rating (Ratings) at the start of each year (in January) and on lagged coerciveness $\left(\operatorname{Coerc}_{t-1}\right)$.

$$
\operatorname{Coerc}_{i, t}=\alpha_{i}+\alpha_{t}+\beta_{1} \operatorname{Coerc}_{i, t-1}+\beta_{2} \text { Ratings }_{i, t}+u_{i, t} .
$$


Table 3: Reverse causality and "surprise" coerciveness

\begin{tabular}{|c|c|c|c|c|c|}
\hline & \multicolumn{5}{|c|}{ Dependent variable } \\
\hline & $\begin{array}{l}\text { Coerc } \\
\text { Index }\end{array}$ & $\begin{array}{l}\text { Coerc } \\
\text { Index }\end{array}$ & $\begin{array}{l}\text { Coerc } \\
\text { Index }\end{array}$ & $\begin{array}{l}\text { Coerc } \\
\text { Index }\end{array}$ & Growth \\
\hline Growt $_{t-1}$ & $\begin{array}{l}-0.0105 \\
(0.0097)\end{array}$ & $\begin{array}{l}-0.0104 \\
(0.0098)\end{array}$ & $\begin{array}{l}-0.0106 \\
(0.0097)\end{array}$ & & \\
\hline Growth $_{t-2}$ & & $\begin{array}{c}-0.0014 \\
(0.0101)\end{array}$ & $\begin{array}{l}-0.0001 \\
(0.0105)\end{array}$ & & \\
\hline Growth $_{t-3}$ & & & $\begin{array}{l}-0.0029 \\
(0.0096)\end{array}$ & & \\
\hline Ratings & & & & $\begin{array}{c}-0.0035^{* *} \\
(0.0015)\end{array}$ & \\
\hline $\operatorname{Coerc}_{t-1}$ & & & & $\begin{array}{c}0.7796^{* * *} \\
(0.0297)\end{array}$ & \\
\hline Surprise Coerc & & & & & $\begin{array}{c}-0.5682^{* * *} \\
(0.1854)\end{array}$ \\
\hline Expected Coerc & & & & & $\begin{array}{c}-0.3085 \\
(0.2321) \\
\end{array}$ \\
\hline Observations & 866 & 865 & 863 & 1,451 & 888 \\
\hline Countries & 43 & 43 & 43 & 60 & 43 \\
\hline Time FE & YES & YES & YES & YES & YES \\
\hline Country FE & YES & YES & YES & YES & YES \\
\hline Standard macro ctrl's & YES & YES & YES & NO & YES \\
\hline$R^{2}$ & 0.6343 & 0.6343 & 0.6311 & 0.5527 & 0.4176 \\
\hline
\end{tabular}

Note: This table shows tests for reverse causality and attempts to distinguish expected from unexpected coerciveness using forward looking ratings data in January of each year. In columns (1) to (4), the dependent variable is the coerciveness index, while in column (5), the dependent variable is the annual growth rate of real GDP per capita, measured in percentage points. Robust standard errors are given in parentheses. In column (5), the standard errors have been adjusted to account for the presence of an imputed regressor bias due to the fact that SurpCoerc and ExpCoerc are not actually observed but estimated with sampling error in regression (4) (Murphy-Topel standard errors). ${ }^{* * *},{ }^{* *}$, and ${ }^{*}$ denote significance at the 1,5 , and 10 per cent levels, respectively.

The rationale is that a start-of-year country credit ratings and the degree of last year's coerciveness should pick up market expectations about the government future payment and negotiation behavior. If this is true, one can interpret the fitted values of this regression as the "expected" part of coerciveness, whereas the residual of the equation should proxy the "unexpected" or "surprise" part of coerciveness. ${ }^{17}$

As our rating measure, we use the Institutional Investor's country credit ratings (Ratings), which have been widely used in the debt crisis literature (see e.g. Reinhart

\footnotetext{
${ }^{17}$ An alternative strategy would be to use a proxy for a country's bargaining power, such as country size or the share of a country's debt stock in total outstanding debts in emerging market. Unfortunately, however, it is difficult to find a good proxy for bargaining power that is time-varying. Country size or relative debt weights, for example, are rather constant over time, so that we cannot include country fixed effects, which are essential for identification. We thank a referee for making this suggestion.
} 
et al., 2003). The ratings are based on information provided by senior economists and sovereign risk analysts at leading global banks and money management firms. Survey participants grade each country's credit risk on a scale from 0 (maximum credit risk) to 100 (minimum credit risk). In the final index, the survey responses are weighted according to the global credit exposure of each participating institution, such that the measure is a reasonable proxy of the average market assessment of a country's willingness and ability to repay.

An important advantage of the Institutional Investor ratings is that they have a much broader coverage than ratings by the three major rating agencies (S\&P, Moody's and Fitch). Indeed, they go back as far as 1978 and cover more than 100 countries. For our purposes, a further crucial advantage is that the II rating scale varies even within debt crises. This differs from most other credit ratings, which simply rate countries as "in default" without further differentiation. During defaults, the II credit score can thus be interpreted as indicating the (perceived and expected) severity of a debt crisis at each point in time. More specifically, the II rating survey is conducted semi-annually, in January and July of each year. Since we are working with annual data, we use the January country credit rating to capture the market's country credit risk assessment at the start of that year.

The results of the first step regression are shown in Column 4 of Table 3. Both lagged coerciveness and start-of-year ratings are highly significant predictors of current coerciveness. In a second step, the residual and the fitted value of the first step regression (interpreted as "surprise" and "expected" coerciveness, respectively) are now included as regressors in our standard growth regression, replacing the original coerciveness index. In order to avoid the problem of biased estimators, due to the fact that the imputed variables are not actually observed, but estimated with sampling error in the first step regression Murphy and Topel (1985), we correct the standard errors according to the procedure proposed by Hardin (2002) and Hole (2006).

The results of the second stage regression are shown in Column 5 of Table 3. Surprise coerciveness (i.e. the unexpected component) is highly significant and negative, while expected coerciveness does not seem to impact a country's growth. We interpret this result as a further sign that our main findings are not driven by reverse causality.

Lastly, we also attempted an instrumental variable strategy. This, however, turned out to be a very difficult task since we need an instrument that is closely correlated with the coerciveness index while being exogenous to GDP growth. The exogeneity assumption is doubtful for any macroeconomic variable. We therefore turned to institutional 
and political variables, such as the timing of democratic elections (using only regular elections, i.e. those foreseen by the electoral cycle) and measures of democratisation. However, these political variables do not exhibit enough variation to qualify as strong instruments for the time-varying coerciveness index. Hence, even though we do find results that roughly support our main findings, we prefer not to show the instrumental variable regressions as they are noisy and not sufficiently credible.

\section{$5 \quad$ Output after default exit}

In this last section, we assess the link between haircuts, coerciveness and GDP growth in the aftermath of default and debt restructuring. We again start with a graphical analysis. Figure 6 depicts the development of real GDP per capita around the end of default, from three years before until five years after the conclusion of a final debt restructuring. The year of crisis exit is labeled as zero (black vertical line) and real GDP is again normalized to 100 in year -1. Panel A uses the full sample of crises and shows rapid growth after the exit from default. On average, countries grow by more than $10 \%$ in the 5 post-crisis years.

Panel B divides the sample into cases of hard and soft default, now using the median haircut size (35.8\%) as separation criterion. This yields 14 cases of hard defaults (with haircuts larger than $35.8 \%$ ) and 15 cases of soft default. ${ }^{18}$ The results are unexpected. The figure shows almost no difference in average GDP growth and the shape of confidence bands between hard and soft defaulters, suggesting that both the level and the dispersion in post-default growth rates are similarly distributed.

The picture is generally confirmed in the regression analysis shown in Table A.4 in the Online Appendix, which follows a similar stepwise strategy as in Section 3. Haircuts and debtor coerciveness are not significant predictors of post-default growth once we control for macroeconomic conditions and time trends. In the baseline regressions, we use a constant 5 year lag measure, but the results do not change if we use lags for each post-crisis year individually. Interestingly, the haircut measure has a positive coefficient in a naïve OLS estimation with time fixed effects only, but the coefficients turns insignificant and negative once we add basic controls and country fixed effects.

Since we find no significant results for the haircut variable, we show results in a much more condensed manner than with regard to the coerciveness index above. What

\footnotetext{
${ }^{18}$ To avoid overlaps, Ecuador 1995 is excluded (another default after 3 years).
} 


\section{Figure 6: Real GDP around the end of default}

(a) Panel A: All defaults

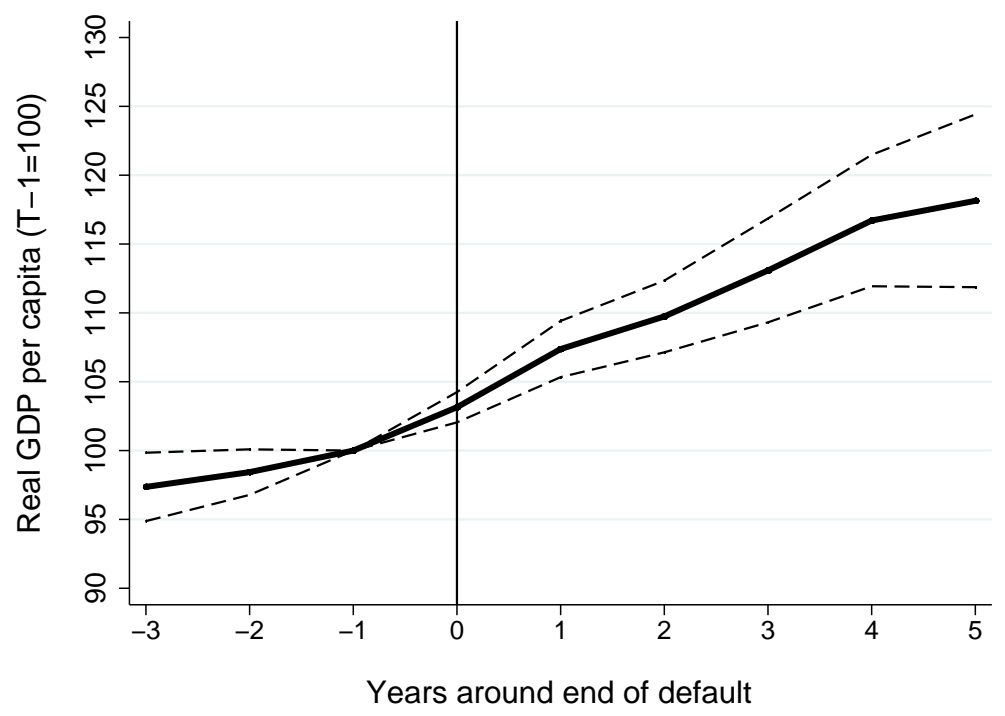

(b) Panel B: Hard and soft defaults

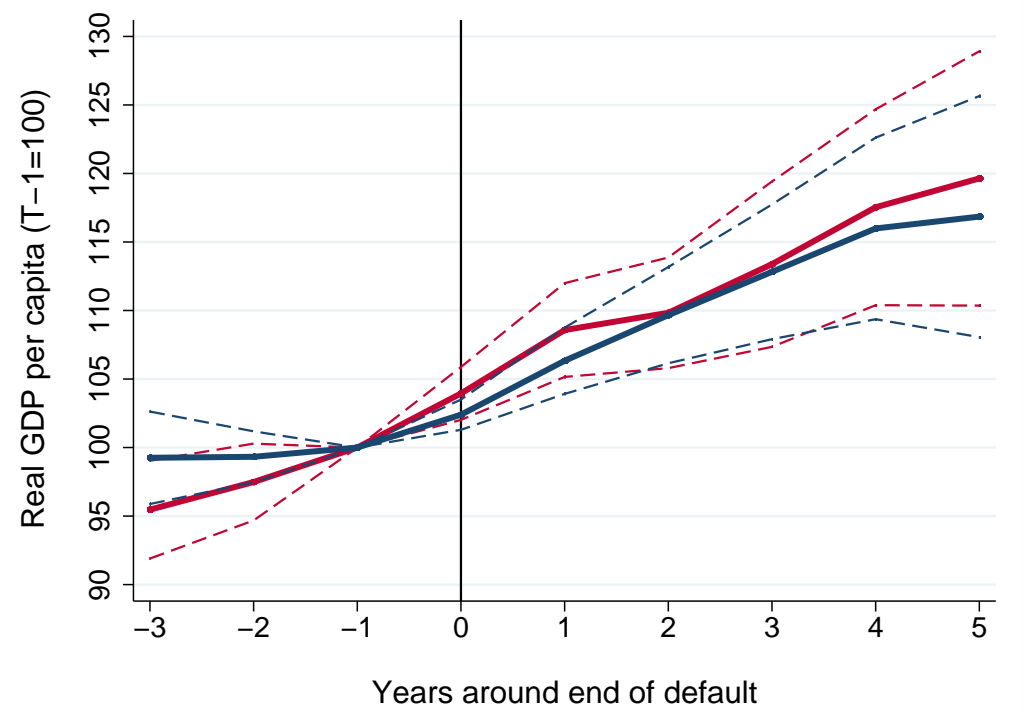

Note: The solid lines show average real GDP per capita from three years before until five years after crisis exit, while the dashed lines are $90 \%$ confidence intervals. Real GDP per capita is normalised to 100 in the year before the final restructuring. Panel A uses the full sample of 29 default episodes, while Panel B splits the sample at the median haircut value of $35.8 \%$ into 14 cases of hard default (haircuts larger than $35.8 \%$, red line) and 15 cases soft default (haircuts below $35.8 \%$, blue line). 
explains the insignificant haircut coefficient after default? This is all the more surprising, since it stands in contrast to the highly significant coerciveness coefficients during default.

One possibility is that only coerciveness affects growth while haircuts do not. However, the results in Column 7 of Table A.4 show that also the lagged (average) coerciveness index is insignificant post-default. The same is true if we inspect the data graphically, analogous to Panel B, but using the average coerciveness index of the crisis to define soft and hard defaulters. Average post-crisis growth is again remarkably similar for the two sub-groups. Hence, in contrast to our result during crises, we do not find direct evidence that the severity of a crisis matters for post-default growth.

Another potential explanation for the insignificant findings is that developing countries benefit from the debt relief effect of high haircuts, as concluded by Arslanalp and Henry (2005) and Reinhart and Trebesch (2016a), thus mitigating any negative reputational effects that high creditor losses could entail. Another interpretation is that the size of the final haircut does not come as a surprise but has already been anticipated by markets in the run up to the restructuring. Any negative effects of high haircuts on growth would materialize earlier, during the often lengthy renegotiation period. This latter explanation is analogous to Levy-Yeyati and Panizza (2011): defaults might be particularly costly in the early phase of distress, when creditors start reacting to the (expected) crisis and the potential losses on their debt holdings. Once these losses have realized, however, and once the formal act of debt restructuring occurs, few additional costs arise.

The results in this section should not be misinterpreted. In particular, they do not imply that imposing high haircuts has no long-lasting effects on growth. As we have explained, identification is difficult and there are competing channels, which are hard to disentangle in the data at hand. Moreover, it is possible that the timing of the restructuring is endogenous, and this may bias the haircut coefficient towards zero. Indeed, both sovereigns and creditors may have an incentive to settle in good times, when default risk is low and growth prospects are good (as shown in the models by Bi, 2008; Benjamin and Wright, 2009). The insignificant result post-default also does not mean that there are no long-term costs of default. As we have shown, defaults can take up to 10 years to resolve. Lower growth numbers for such an extended period can have substantial cumulative wealth effects.

Finally, we should emphasize that the results in this analysis stand in contrast to Cruces and Trebesch (2013). Here, we do not find that high haircuts are followed by 
lower growth in the post-default period, while Cruces and Trebesch (2013) document that higher haircuts are associated with higher sovereign bond yields later on and delayed reaccess to international capital markets. One explanation for these disparate results is the phenomenon of "Phoenix miracles" descibed by (Calvo et al., 2006). Emerging markets often see a quick recovery of output after financial crises, even if credit and capital flows remain depressed and market access is unfavorable.

\section{Conclusion}

In this paper, we move beyond the classic dichotomous treatment of sovereign defaults and use continuous measures on government payment and negotiation behavior and the size of creditor losses in debt crises. We show that coercive actions towards external creditors are associated with a much steeper drop in output when compared to cases with consensual crisis resolution.

On average, "hard" defaults are associated with a 2 to 4 percentage points lower growth rate during the crisis, depending on the sample and estimation method. Surprisingly however, we do not find that high haircuts and debtor coerciveness are associated with lower growth in the post-crisis period. The cost of "hard" defaults thus seems to

be most relevant during debt crisis episodes (which can take many years) but not so much afterwards.

Our results support the view that the cost of debt crises depend to an important degree on the severity of default and not only on its occurrence. This is in line with Aguiar and Amador (2014) who discuss why it is important to consider "richer notions of default". More generally, the results can be interpreted as evidence for the existence of a tradeoff: coercive debtor policies and high haircuts may have social and political benefits in the short-run, but they also imply lower growth in the course of the crisis, thus delaying recovery. 


\section{References}

Abbas, S. M. A., N. Belhocine, A. A. Elganainy, and M. A. Horton (2010): "A Historical Public Debt Database," IMF Working Paper 10/245, International Monetary Fund.

Adam, K. And M. Grill (2013): "Optimal Sovereign Default," Discussion Paper 09/2013, Deutsche Bundesbank, Research Centre.

Aggarwal, V. K. (1996): Debt Games: Strategic Interaction in International Debt Rescheduling, Cambridge University Press.

Aguiar, M. And M. Amador (2014): "Sovereign Debt," in Handbook of International Economics, ed. by K. R. Elhanan Helpman and G. Gopinath, Elsevier, vol. 5, chap. 11, 647-687.

Aguiar, M., M. Amador, E. Farhi, and G. Gopinath (2013): "Crisis and Commitment: Inflation Credibility and the Vulnerability to Sovereign Debt Crises," NBER Working Paper 19516, National Bureau of Economic Research, Inc.

Aguiar, M. and G. Gopinath (2006): "Defaultable Debt, Interest Rates and the Current Account," Journal of International Economics, 69, 64-83.

Andritzky, J. (2006): Sovereign Default Risk Valuation: Implications of Debt Crises and Bond Restructurings, Springer.

Arellano, C. (2008): "Default Risk and Income Fluctuations in Emerging Economies," American Economic Review, 98, 690-712.

Arellano, C., X. Mateos-Planas, and J.-V. Ríos-Rull (2013): "Partial Default," Mimeo, NBER.

Arellano, C. And A. Ramanarayanan (2012): "Default and the Maturity Structure in Sovereign Bonds," Journal of Political Economy, 120, 187 - 232.

Arslanalp, S. And P. B. Henry (2005): "Is Debt Relief Efficient?" Journal of Finance, 60, 1017-1051.

Arteta, C. and G. Hale (2008): "Sovereign Debt Crises and Credit to the Private Sector," Journal of International Economics, 74, 53-69.

Asonuma, T. and C. Trebesch (2016): "Sovereign Debt Restructurings: Preemptive Or Post-Default," Journal of the European Economic Association, 14, 175-214. 
Barro, R. J. (1977): "Unanticipated Money Growth and Unemployment in the United States," American Economic Review, 67, 101-15.

Barro, R. J. And J.-W. LeE (2010): “A New Data Set of Educational Attainment in the World, 1950 - 2010," NBER Working Paper 15902, National Bureau of Economic Research, Inc.

Beck, N. And J. N. Katz (2011): "Modeling Dynamics in Time-Series-Cross-Section Political Economy Data," Annual Review of Political Science, 14, 331-352.

Benjamin, D. And M. L. J. Wright (2009): "Recovery Before Redemption: A Theory Of Delays In Sovereign Debt Renegotiations," CAMA Working Paper 200915, Australian National University, Centre for Applied Macroeconomic Analysis.

Bi, R. (2008): "Beneficial Delays in Debt Restructuring Negotiations," IMF Working Papers 08/38, International Monetary Fund.

Bocola, L. (2015): "The Pass-Through of Sovereign Risk," Working Papers 722, Federal Reserve Bank of Minneapolis.

Bolton, P. And O. Jeanne (2007): "Structuring and Restructuring Sovereign Debt: The Role of a Bankruptcy Regime," Journal of Political Economy, 115, 901-924.

- (2011): "Sovereign Default Risk and Bank Fragility in Financially Integrated Economies," IMF Economic Review, 59, 162-194.

Borensztein, E. And U. Panizza (2009): "The Costs of Sovereign Default," IMF Staff Paper, 56, 683-741.

Brambor, T., W. R. Clark, and M. Golder (2006): "Understanding interaction models: improving empirical analyses," Political Analysis, 14(1).

Bulow, J. And K. Rogoff (1989): "Sovereign Debt: Is to Forgive to Forget?" American Economic Review, 79, 43-50.

Calvo, G. A. (1988): "Servicing the Public Debt: The Role of Expectations," American Economic Review, 78, 647-61.

Calvo, G. A., A. Izquierdo, And E. Talvi (2006): "Sudden Stops and Phoenix Miracles in Emerging Markets." American Economic Review, 96(2), 405-410.

Cameron, C. A. And P. K. Tivedi (2005): Microeconometrics, Methods and Applications, Cambridge University Press. 
Catao, L. And R. Mano (2015): "Default Premium," IMF Working Papers 15/167, International Monetary Fund.

Chatterjee, S. And B. Eyigungor (2012): "Maturity, Indebtedness, and Default Risk," American Economic Review, 102, 2674-99.

Cline, W. R. (1995): International Debt Reexamined, 46, Washington D.C.: Peterson Institute for International Economics.

(2004): "Private Sector Involvement in Financial Crisis Resolution: Definition, Measurement, and Implementation." in Fixing Financial Crises in the Twenty-first Century, ed. by A. Haldane, Routledge, 61-94.

Cole, H., D. Neuhann, and G. Ordonez (2016): "Debt Crises: For Whom the Bell Tolls," NBER Working Papers 22330, National Bureau of Economic Research, Inc.

Cole, H. L. And P. J. Kehoe (1997): "Reviving Reputation Models of International Debt," Quarterly Review, 21, 21-30.

_ (1998): "Models of Sovereign Debt: Partial versus General Reputations," International Economic Review, 39, 55-70.

Corsetti, G. And L. Dedola (2012): "The Mystery of the Printing Press: Selffulfilling Debt Crises and Monetary Sovereignty," CEPR Discussion Paper No. 9358.

Cruces, J. J. and C. Trebesch (2013): "Sovereign Defaults: The Price of Haircuts," American Economic Journal: Macroeconomics, 5, 85-117.

De Paoli, B., G. Hoggarth, and V. Saporta (2009): "Output Costs of Sovereign Crises: Some Empirical Estimates," Bank of England Working Paper 362, Bank of England.

D'Erasmo, P. and E. G. Mendoza (2016): "Distributional Incentives In An Equilibrium Model Of Domestic Sovereign Default," Journal of the European Economic Association, 14, 7-44.

Dubey, P., J. Geanakoplos, and M. Shubik (2005): "Default and Punishment in General Equilibrium," Econometrica, 73, 1-37.

Eaton, J. And R. Fernandez (1995): "Sovereign debt," in Handbook of International Economics, ed. by G. M. Grossman and K. Rogoff, Elsevier, vol. 3, chap. 3, 2031-2077. 
Eaton, J. And M. Gersovitz (1981): "Debt with Potential Repudiation: Theoretical and Empirical Analysis," Review of Economic Studies, 48, 289-309.

Eichengreen, B. (1991): "Historical Research on International Lending and Debt," The Journal of Economic Perspectives, 5, 149-169.

Enderlein, H., C. Trebesch, And L. von Daniels (2012): "Sovereign Debt Disputes: A Database on Government Coerciveness during Debt Crises," Journal of International Money and Finance, 31, 250-266.

FurCeri, D. AND A. ZdzienickA (2012): "How Costly are Debt Crises?" Journal of International Money and Finance, 31, 726-742.

Gennaioli, N., A. Martin, And S. Rossi (2014a): "Banks, Government Bonds, and Default: What do the Data Say?" CEPR Discussion Paper 10044, C.E.P.R. Discussion Paper.

- (2014b): "Sovereign Default, Domestic Banks, and Financial Institutions," Journal of Finance, 69, 819-866.

Goldberger, A. S. (1991): A Course in Econometrics, Harvard University Press.

Gornemann, N. M. (2016): "Sovereign Default, Private Investment, and Economic Growth," Journal of the European Economic Association, 14, 215-251.

Grossman, H. And J. van HuycK (1988): "Sovereign Debt as a Contingent Claim: Excusable Default, Repudiation, and Reputation," American Economic Review, 78, 1088-1097.

Hardin, J. W. (2002): "The Robust Variance Estimator for Two-Stage Models," Stata Journal, 2, 253-266.

Hatchondo, J. C. And L. Martinez (2012): "Debt Dilution and Sovereign Default Risk," Working Paper 10-08, Federal Reserve Bank of Richmond.

Hatchondo, J. C., L. Martinez, And C. Sosa Padilla (2014): "Voluntary sovereign debt exchanges," Journal of Monetary Economics, 61, 32-50.

Hebert, B. And J. Schreger (2016): "The Costs of Sovereign Default: Evidence from Argentina," NBER Working Papers 22270, National Bureau of Economic Research, Inc. 
Hole, A. R. (2006): "Calculating Murphy-Topel Variance Estimates in Stata: A Simplified Procedure," Stata Journal, 6, 521-529.

Hurwicz, L. (1950): "Least Square Bias in Time Series," in Statistical Inference in Dynamic Economic Models, ed. by T. C. Koopmans, Wiley, chap. XV, 365-383.

Institute of International Finance (2013): "Principles for Stable Capital Flows and Fair Debt Restructuring, Report on Implementation by the Principles Consultative Group," Institute of International Finance.

International Monetary Fund (1999): IMF Policy on Lending into Arrears to Private Creditors, International Monetary Fund.

- (2002): Fund Policy on Lending into Arrears to Private Creditors - Further Consideration of the Good Faith Criterion, International Monetary Fund.

Judson, R. A. And A. L. Owen (1999): "Estimating Dynamic Panel Data Models: A Guide for Macroeconomists," Economics Letters, 65, 9-15.

Kennedy, P. (2003): A Guide to EconometricsA Guide to Econometrics, MIT Press, 5 ed.

Kletzer, K. M. And B. D. Wright (2000): "Sovereign Debt as Intertemporal Barter," American Economic Review, 90, 621-639.

Kuvshinov, D. And K. Zimmermann (2016): "Sovereigns going bust: estimating the cost of default," Bonn Econ Discussion Papers bgse $01_{2} 016$, Univer sityof Bonn, Germany.

Laeven, L. And F. Valencia (2012): "Systemic Banking Crises Database: An Update," IMF Working Paper 12/163, International Monetary Fund.

Levy-Yeyati, E. And U. Panizza (2011): "The Elusive Costs of Sovereign Defaults," Journal of Development Economics, 94, 95-105.

Marchesi, S. (2016): "Life after default? Private vs. official sovereign debt restructurings," Development Working Papers 398, Centro Studi Luca d'Agliano, University of Milano.

MendozA, E. G. And V. Z. Yue (2012): "A General Equilibrium Model of Sovereign Default and Business Cycles," The Quarterly Journal of Economics, 127, 889-946. 
Murphy, K. M. and R. H. Topel (1985): "Estimation and Inference in Two-Step Econometric Models," Journal of Business 83 Economic Statistics, 3, 370-79.

Nickell, S. J. (1981): "Biases in Dynamic Models with Fixed Effects," Econometrica, 49, 1417-26.

Obstfeld, M. and A. M. Taylor (2003): "Sovereign Risk, Credibility and the Gold Standard: 1870-1913 versus 1925-31," Economic Journal, 113, 241-275.

Panizza, U., F. Sturzenegger, and J. Zettelmeyer (2009): "The Economics and Law of Sovereign Debt and Default," Journal of Economic Literature, 47, 651-98.

Reinhart, C. M., V. R. Reinhart, and K. S. Rogoff (2012): "Public Debt Overhangs: Advanced-Economy Episodes since 1800," Journal of Economic Perspectives, 26, 69-86.

Reinhart, C. M., K. S. Rogoff, and M. A. Savastano (2003): "Debt Intolerance," Brookings Paper on Economic Activity, 34, 1-74.

Reinhart, C. M. and C. Trebesch (2016a): "Sovereign Debt Relief And Its Aftermath," Journal of the European Economic Association, 14, 215-251.

_ (2016b): "The International Monetary Fund: 70 Years of Reinvention," Journal of Economic Perspectives, 30, 3-28.

Rose, A. K. (2005): "One reason countries pay their debts: renegotiation and international trade," Journal of Development Economics, 77, 189-206.

Roubini, N. (2004): "Private Sector Involvement in Crisis Resolution and Mechanisms for Dealing with Sovereign Debt Problems." in Fixing Financial Crises in the Twentyfirst Century, ed. by A. Haldane, Routledge, 61-94.

Roubini, N. And B. Setser (2004): Bailouts or Bail-ins? Responding to Financial Crises in Emerging Economies, no. 378 in Peterson Institute Press: All Books, Peterson Institute for International Economics.

SAndleRIS, G. (2008): "Sovereign Defaults: Information, Investment and Credit," Journal of International Economics, 76, $267-275$.

Sandleris, G. And M. L. J. Wright (2014): "The Costs of Financial Crises: Resource Misallocation, Productivity, and Welfare in the 2001 Argentine Crisis," Scandinavian Journal of Economics, 116, 87-127. 
Standard \& Poor's (2011): "Sovereign Defaults and Rating Transition Data: 2010 Update," Ratingsdirect, Standard \& Poor's.

Sturzenegger, F. (2004): "Tools for the Analysis of Debt Problems," Journal of Restructuring Finance, 01, 201-223.

Sturzenegger, F. And J. Zettelmeyer (2007): Debt Defaults and Lessons from a Decade of Crises, The MIT Press.

- (2008): "Haircuts: Estimating Investor Losses in Sovereign Debt Restructurings, 1998-2005," Journal of International Money and Finance, 27, 780-805.

Tomz, M. And M. L. Wright (2013): "Empirical Research on Sovereign Debt and Default," Annual Review of Economics, 5, 247-272.

Tomz, M. And M. L. J. Wright (2007): "Do Countries Default in "Bad Times"?" Journal of the European Economic Association, 5, 352-360.

Trebesch, C. (2009): "The Cost of Aggressive Sovereign Debt Policies: How Much is the Private Sector Affected?" IMF Working Paper 09/29, International Monetary Fund.

Wright, M. L. J. (2002): "Reputation and Sovereign Debt," Working Paper.

Yue, V. Z. (2010): "Sovereign Default and Debt Renegotiation," Journal of International Economics, 80, 176-187.

Zame, W. R. (1993): "Efficiency and the Role of Default When Security Markets Are Incomplete," American Economic Review, 83, 1142-1164. 
Online Appendix 
Figure A.1: Coerciveness index: descriptive statistics

(a) Distribution of coerciveness index

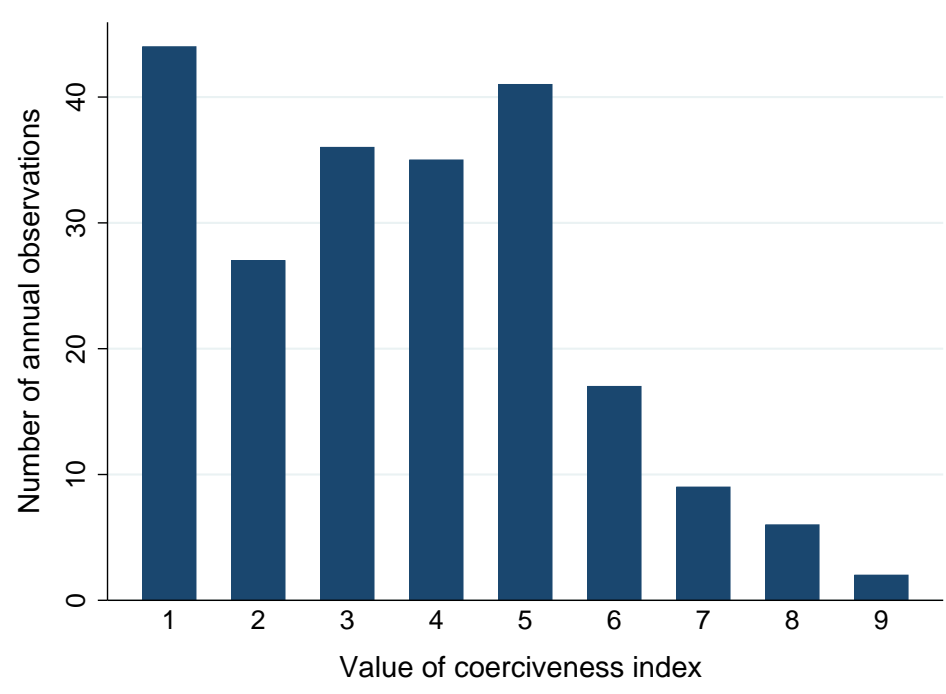

(b) Summary statistics on the coerciveness index and its subindicators

\begin{tabular}{lccc}
\hline \hline Variable & Frequency & Min & Max \\
\hline Coerciveness index & 217 & 0 & 9 \\
Payments missed & 157 & 0 & 1 \\
Unilateral suspension & 128 & 0 & 1 \\
Full suspension & 56 & 0 & 1 \\
Freeze on assets & 27 & 0 & 1 \\
Negotiations breakdown & 97 & 0 & 1 \\
Moratorium declaration & 28 & 0 & 1 \\
Threats to repudiate & 38 & 0 & 1 \\
Data disputes & 21 & 0 & 1 \\
Forced restructuring & 13 & 0 & 1 \\
\hline \hline
\end{tabular}


Figure A.2: Haircuts: descriptive statistics

(a) Size of haircuts across countries and time

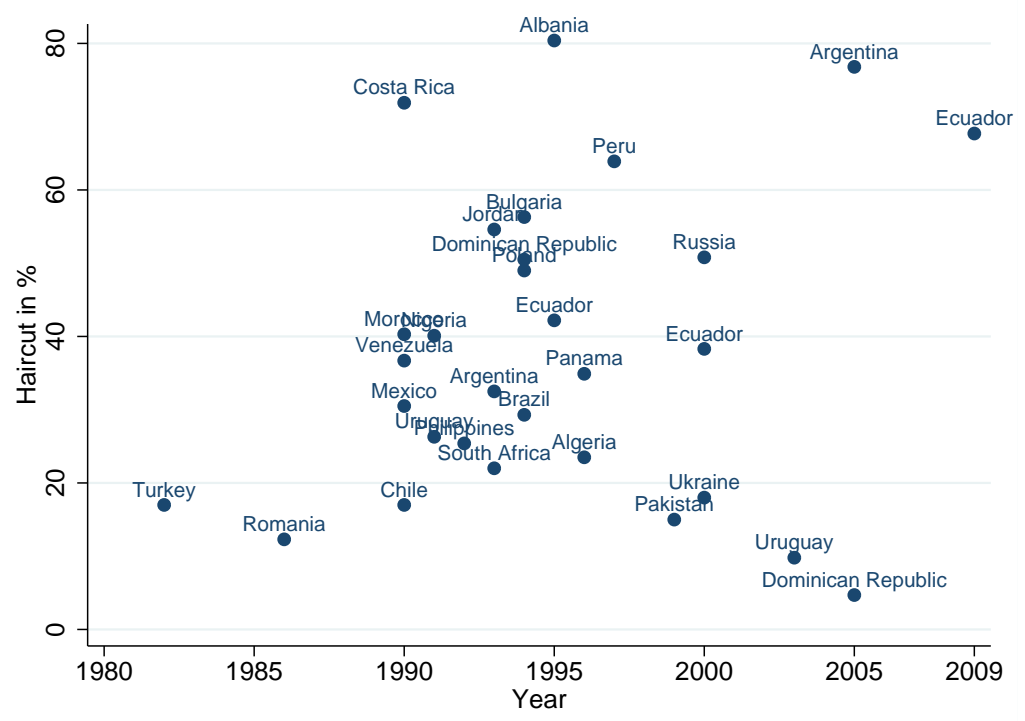

(b) Descriptive statistics

\begin{tabular}{lcccccc}
\hline \hline & \# of obs. & Min. & Max. & Mean & Median & Std. Dev. \\
\hline Haircuts & 30 & $5 \%$ & $80 \%$ & $38 \%$ & $36 \%$ & $21 \%$ \\
\hline \hline
\end{tabular}


Figure A.3: Government coerciveness and crisis duration

(a) Panel A: Level of debtor coerciveness and default duration

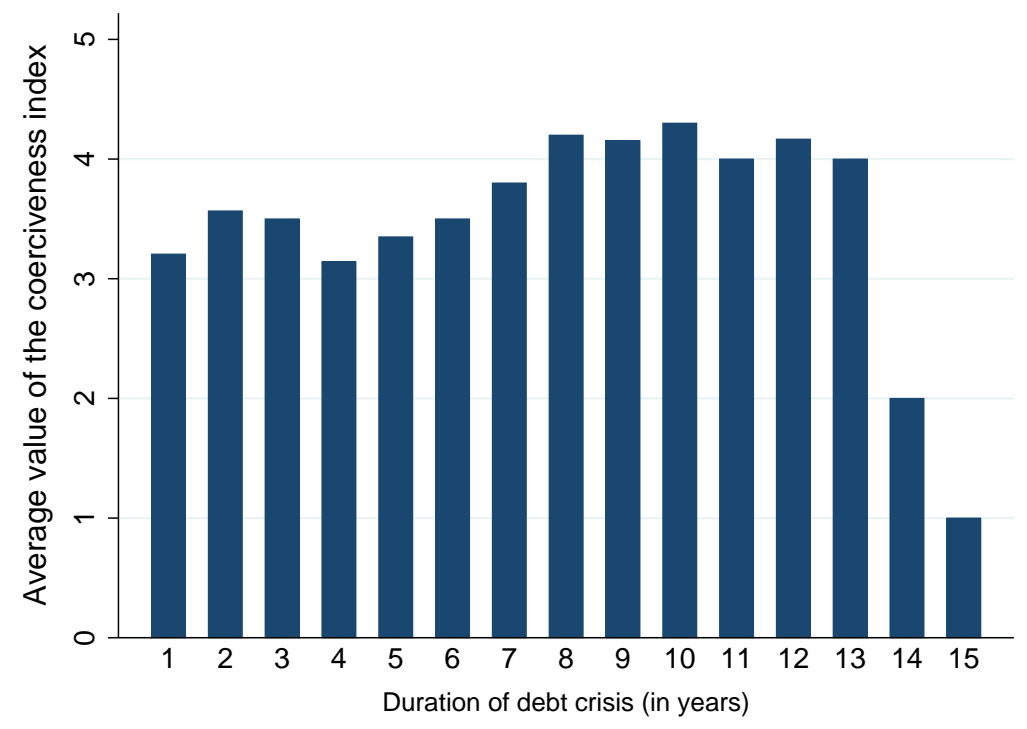

(b) Panel B: Changes in debtor coerciveness and default duration

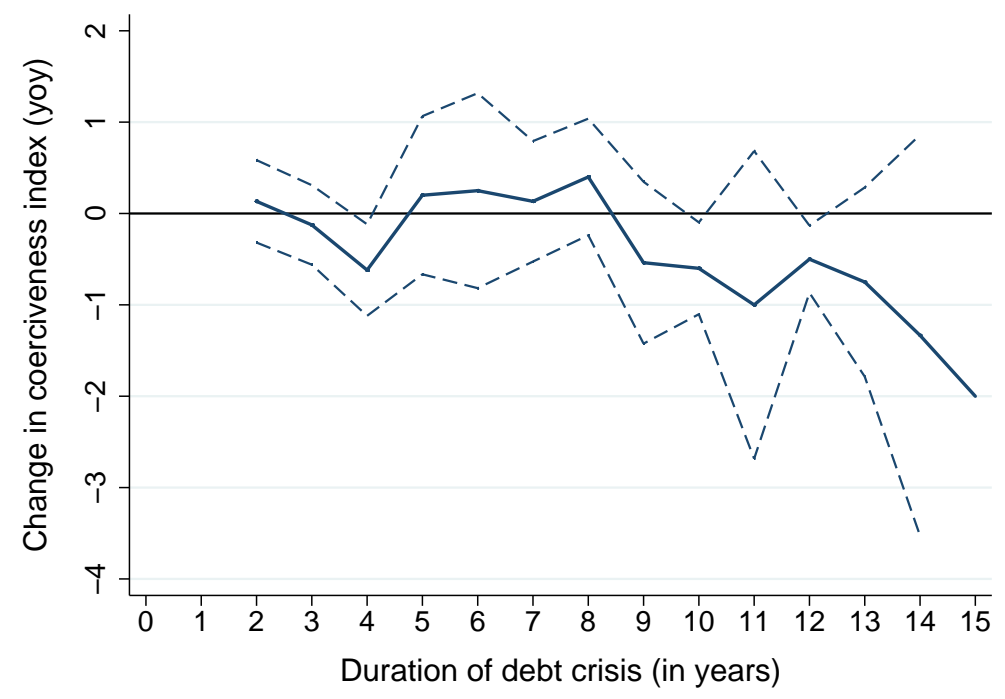

Note: Panel A shows the average coerciveness index value for each debt crisis year. In the first year of default the coerciveness index has an average value of 3.2, in the second year 3.6, and so on. Panel $\mathrm{B}$ shows average year-on-year changes in the coerciveness index, starting from the second year of a debt crisis. The dashed lines indicate $90 \%$ confidence intervals. Note that the number of observations declines notably in default duration. For example the 15th year of default is observed just once (Peru 1997), while there are only three observations in the 14th default year (Peru, Panama and Ecuador). 
Table A.1: Country sample and debt crisis years

\begin{tabular}{|c|c|}
\hline \multicolumn{2}{|c|}{ List of defaulters ( 25 countries), with years of debt crisis } \\
\hline Albania: 1980-2009 (1991-1995) & Pakistan: 1980-2009 (1998-1999) \\
\hline Algeria: 1980-2009 (1991-1996) & Panama: 1980-2009 (1983-1996) \\
\hline $\begin{array}{l}\text { Argentina: 1980-2009 (1982-1993; } \\
\text { 2001-2005) }\end{array}$ & Peru: 1981-2009 (1983-1997) \\
\hline Brazil: 1980-2009 (1983-1994) & Philippines: 1980-2009 (1983-1992) \\
\hline Bulgaria: 1980-2009 (1990-1994) & Poland: 1991-2009 (1991-1994) \\
\hline Chile: 1980-2009 (1983-1990) & Romania: 1980-2009 (1981-1983; 1986) \\
\hline Costa Rica: 1980-2009 (1981-1990) & Russia: 1989-2009 (1991-2000) \\
\hline $\begin{array}{l}\text { Dominican Republic: 1980-2009 (1982- } \\
\text { 1994; 2004-2005) }\end{array}$ & $\begin{array}{l}\text { South Africa: 1980-2009 (1985-1987; } \\
\text { 1989;1993) }\end{array}$ \\
\hline $\begin{array}{l}\text { Ecuador: 1980-2009 (1982-1995; 1999- } \\
\text { 2000; 2008-2009) }\end{array}$ & Turkey: 1980-2009 (1981-1982) \\
\hline Jordan: 1980-2009 (1989-1993) & Ukraine: 1987-2009 (1998-2000) \\
\hline Mexico: 1980-2009 (1982-1990) & Uruguay: 1980-2009 (1983-1991; 2003) \\
\hline Morocco: 1980-2009 (1983-1990) & $\begin{array}{l}\text { Venezuela: 1980-2009 (1982-1990; } \\
\text { 2004-2005) }\end{array}$ \\
\hline \multicolumn{2}{|l|}{ Nigeria: 1980-2000 (1982-1992) } \\
\hline \multicolumn{2}{|l|}{ List of non-defaulter (36 countries) } \\
\hline Armenia: $1995-2009$ & Lithuania: 1990-2009 \\
\hline Azerbaijan: 1995-2009 & Malaysia: 1980-2009 \\
\hline Bahrain: 1980-2009 & Mauritius: 1980-2009 \\
\hline Belarus: 1990-2009 & Namibia: 1980-2009 \\
\hline Botswana: 1980-2009 & Oman: 1980-2009 \\
\hline China: 1980-2009 & Papua New Guinea: 1980-2009 \\
\hline Colombia: 1980-2009 & Puerto Rico: 1980-2009 \\
\hline Egypt: 1980-2009 & Qatar: 1995-2009 \\
\hline El Salvador: 1980-2009 & Saudi Arabia: 1980-2009 \\
\hline Georgia: 1980-2009 & Singapore: 1980-2009 \\
\hline Hong Kong: 1980-2009 & Slovak Republic: 1984-2009 \\
\hline Hungary: 1980-2009 & Swaziland: 1980-2009 \\
\hline India: $1980-2009$ & Syria: $1980-2009$ \\
\hline Kazakhstan: 1990-2009 & Thailand: 1980-2009 \\
\hline Kuwait: 1995-2009 & Tunisia: 1980-2009 \\
\hline Latvia: 1980-2009 & Turkmenistan: 1987-2009 \\
\hline Lebanon: 1992-2009 & United Arab Emirates: 1980-2009 \\
\hline Libya: 1999-2009 & Uzbekistan: 1987-2009 \\
\hline
\end{tabular}


Table A.2: Variable definitions

\begin{tabular}{|c|c|c|}
\hline Variable & Definition & Sources \\
\hline Growth & $\begin{array}{l}\text { Annual growth rate of real GDP per capita (in per- } \\
\text { cent) }\end{array}$ & $\begin{array}{l}\text { World Development Indi- } \\
\text { cators }\end{array}$ \\
\hline Default & $\begin{array}{l}\text { Dummy variable taking on a value of one for each } \\
\text { year a country has been listed as being in default by } \\
\text { Standard \& Poor's }\end{array}$ & Standard \& Poor's \\
\hline $\operatorname{Inv} / G D P$ & Investment to GDP ratio & $\begin{array}{l}\text { World Development Indi- } \\
\text { cators }\end{array}$ \\
\hline$\Delta P o p$ & Annual growth rate of population (in percent) & $\begin{array}{l}\text { World Development Indi- } \\
\text { cators }\end{array}$ \\
\hline $\log ($ Pop $)$ & Natural logarithm of total population (in million) & $\begin{array}{l}\text { World Development Indi- } \\
\text { cators }\end{array}$ \\
\hline SecEdu & $\begin{array}{l}\text { Share of population that attained secondary schooling } \\
\text { (in percent) }\end{array}$ & Barro and Lee (2010) \\
\hline GovtCons $_{t-1}$ & $\begin{array}{l}\text { Lagged annual growth rate of government consump- } \\
\text { tion expenditure (in percent) }\end{array}$ & $\begin{array}{l}\text { World Development Indi- } \\
\text { cators }\end{array}$ \\
\hline CivLib & $\begin{array}{l}\text { Annual index value of the civil liberties index pub- } \\
\text { lished by Freedom House in its annual Freedom in the } \\
\text { World report. The index ranges from } 1 \text { (highest de- } \\
\text { gree of freedom) to } 7 \text { (lowest degree of freedom) }\end{array}$ & $\begin{array}{l}\text { Freedom House Freedom } \\
\text { in the World }\end{array}$ \\
\hline$\Delta T o T$ & $\begin{array}{l}\text { Annual rate of change in current price value of exports } \\
\text { of goods and services deflated by the import price in- } \\
\text { dex (exports as capacity to import) }\end{array}$ & $\begin{array}{l}\text { World Development Indi- } \\
\text { cators }\end{array}$ \\
\hline Openness & $\begin{array}{l}\text { Ratio of average exports plus imports } \quad(= \\
\frac{\text { Exports+Imports }}{2} \text { ) to GDP (in percent) }\end{array}$ & $\begin{array}{l}\text { World Development Indi- } \\
\text { cators }\end{array}$ \\
\hline BankingCrisis & $\begin{array}{l}\text { Dummy variable with a value of one at the beginning } \\
\text { of a banking crisis }\end{array}$ & $\begin{array}{l}\text { Laeven and Valencia } \\
(2012)\end{array}$ \\
\hline $\begin{array}{l}\text { Political } \\
\text { Risk }\end{array}$ & $\begin{array}{l}\text { ICRG Political Risk Index, ranging from a minimum } \\
\text { of } 0 \text { to a maximum of } 100\end{array}$ & Political Risk Group \\
\hline GovChange & $\begin{array}{l}\text { Dummy variable with a value of one in years with a } \\
\text { change in the executive }\end{array}$ & $\begin{array}{l}\text { Database of Political In- } \\
\text { stitutions (DPI) } 2012\end{array}$ \\
\hline CurrencyCrisis & $\begin{array}{l}\text { Dummy variable with a value of one at the beginning } \\
\text { of a currency crisis }\end{array}$ & $\begin{array}{l}\text { Laeven and Valencia } \\
(2012)\end{array}$ \\
\hline Debt/GDP & Ratio of government debt to GDP (in percent) & Abbas et al. (2010) \\
\hline Ratings & $\begin{array}{l}\text { Institutional Investor's Country Credit Rating issued } \\
\text { at the start of each year. The credit rating scale } \\
\text { ranges from zero (extremely high credit risk) to } 100 \\
\text { (extremely low credit risk) }\end{array}$ & $\begin{array}{l}\text { Institutional Investor } \\
\text { Magazine }\end{array}$ \\
\hline$I M F_{t-1}$ & $\begin{array}{l}\text { Dummy variable with a value of one in case of an } \\
\text { ongoing IMF program }\end{array}$ & $\begin{array}{l}\text { Reinhart and Trebesch } \\
(2016 \mathrm{~b})\end{array}$ \\
\hline
\end{tabular}


Table A.3: Summary statistics - main variables

\begin{tabular}{|c|c|c|c|c|}
\hline Variable & Mean & Std. Dev. & Min & Max \\
\hline Growth & 2.03884 & 5.774445 & -45.32511 & 33.03048 \\
\hline Coerc & 0.4727932 & 1.410846 & 0 & 9 \\
\hline Haircut & 37.92333 & 20.67408 & 4.7 & 80.4 \\
\hline Default & 0.1269649 & 0.3330344 & 0 & 1 \\
\hline Inv $/ G D P$ & 0.2399193 & 0.0751849 & 0.02388 & 0.72408 \\
\hline$\triangle P o p$ & 1.727398 & 1.885407 & -2.62465 & 20.42816 \\
\hline $\log (P o p)$ & 2.457494 & 1.644205 & -1.027342 & 7.193971 \\
\hline$S e c E d u$ & 46.93156 & 20.18757 & 9.599999 & 93.49851 \\
\hline GovtCons $_{t-1}$ & 3.842325 & 7.82335 & -44.84714 & 83.22173 \\
\hline CivLib & 3.990903 & 1.618302 & 1 & 7 \\
\hline$\Delta T_{o} T$ & 0.0676785 & 0.1579326 & -0.7147055 & 1.122298 \\
\hline Openness & 88.8763 & 62.82052 & 11.54567 & 460.4711 \\
\hline BankingCrisis & 0.036208 & 0.1868689 & 0 & 1 \\
\hline Political Risk & 64.26955 & 10.82045 & 29.5 & 89.12 \\
\hline GovChange & 0.1580328 & 0.3648914 & 0 & 1 \\
\hline CurrencyCrisis & 0.041717 & 0.2000023 & 0 & 1 \\
\hline Debt/GDP & 51.46241 & 36.4501 & 0 & 289.6 \\
\hline Ratings & 41.97108 & 17.4068 & 6.4 & 93.1 \\
\hline$I M F_{t-1}$ & 0.3345888 & 0.4719947 & 0 & 1 \\
\hline
\end{tabular}


Table A.4: Haircuts, coerciveness, and post-default GDP growth

\begin{tabular}{|c|c|c|c|c|c|c|}
\hline & $\begin{array}{c}(1) \\
\text { Plain I }\end{array}$ & $\begin{array}{c}(2) \\
\text { Plain II }\end{array}$ & $\begin{array}{c}(3) \\
\text { Macro } \\
\text { Controls }\end{array}$ & $\begin{array}{c}(4) \\
\text { Country FE }\end{array}$ & $\begin{array}{c}(5) \\
\text { Addition. } \\
\text { Controls }\end{array}$ & $\begin{array}{c}6) \\
\text { Average } \\
\text { Coerc }\end{array}$ \\
\hline $\begin{array}{l}\text { Haircut } \\
\text { (5yr lag) }\end{array}$ & $\begin{array}{c}0.0255^{* * *} \\
(0.0089)\end{array}$ & $\begin{array}{l}0.0315^{*} \\
(0.0179)\end{array}$ & $\begin{array}{l}-0.0218 \\
(0.0142)\end{array}$ & $\begin{array}{l}-0.0195 \\
(0.0184)\end{array}$ & $\begin{array}{c}-0.0223 \\
(0.0143)\end{array}$ & \\
\hline $\begin{array}{l}\text { Default } \\
\text { (5yr lag) } \\
\text { IMF } F_{t-1} \\
\text { (Dummy) }\end{array}$ & & $\begin{array}{l}-0.3056 \\
(0.7332)\end{array}$ & $\begin{array}{l}1.4767^{* *} \\
(0.6371)\end{array}$ & $\begin{array}{l}1.4866^{*} \\
(0.8668)\end{array}$ & $\begin{array}{c}0.6421 \\
(0.6912) \\
0.4873 \\
(0.3505)\end{array}$ & $\begin{array}{c}0.8809 \\
(0.6296)\end{array}$ \\
\hline $\begin{array}{l}\text { Coerc } \\
\text { (5yr lag) }\end{array}$ & & & & & & $\begin{array}{l}-0.0791 \\
(0.1360)\end{array}$ \\
\hline $\operatorname{Inv} / G D P$ & & & $\begin{array}{c}17.8510^{* * *} \\
(1.9699)\end{array}$ & $\begin{array}{c}19.3975^{* * *} \\
(3.3316)\end{array}$ & $\begin{array}{c}23.3745^{* * *} \\
(3.6779)\end{array}$ & $\begin{array}{c}17.7085^{* * *} \\
(1.9629)\end{array}$ \\
\hline$\triangle P o p$ & & & $\begin{array}{c}-0.4058^{* *} \\
(0.1698)\end{array}$ & $\begin{array}{l}-0.0595 \\
(0.4140)\end{array}$ & $\begin{array}{c}-1.2373^{* * *} \\
(0.3206)\end{array}$ & $\begin{array}{c}-0.3985^{* *} \\
(0.1709)\end{array}$ \\
\hline $\log ($ Pop $)$ & & & $\begin{array}{l}-0.0516 \\
(0.0853)\end{array}$ & $\begin{array}{c}0.9431 \\
(3.2905)\end{array}$ & $\begin{array}{c}7.4477^{* * *} \\
(2.7948)\end{array}$ & $\begin{array}{l}-0.0378 \\
(0.0855)\end{array}$ \\
\hline SecEdu & & & $\begin{array}{c}0.0300^{* * *} \\
(0.0086)\end{array}$ & $\begin{array}{c}0.0385 \\
((0.0507)\end{array}$ & $\begin{array}{c}0.0458 \\
(0.0380)\end{array}$ & $\begin{array}{c}0.0294^{* * *} \\
(0.0086)\end{array}$ \\
\hline GovtCons $_{t-1}$ & & & $\begin{array}{c}0.1005^{* * *} \\
(0.0216)\end{array}$ & $\begin{array}{c}0.0896^{* * *} \\
(0.0222)\end{array}$ & $\begin{array}{c}0.0797^{* * *} \\
(0.0262)\end{array}$ & $\begin{array}{c}0.0975^{* * *} \\
(0.0219)\end{array}$ \\
\hline CivLib & & & $\begin{array}{c}0.0318 \\
(0.1014)\end{array}$ & $\begin{array}{c}0.1071 \\
(0.2745)\end{array}$ & $\begin{array}{c}0.0634 \\
(0.2354)\end{array}$ & $\begin{array}{c}0.0271 \\
(0.1021)\end{array}$ \\
\hline$\Delta T o T$ & & & $\begin{array}{c}9.5672^{* * *} \\
(1.4157)\end{array}$ & $\begin{array}{c}9.8570^{* * * *} \\
(1.6596)\end{array}$ & $\begin{array}{c}8.7619^{* * * *} \\
(1.1828)\end{array}$ & $\begin{array}{c}9.4561^{* * *} \\
(1.4208)\end{array}$ \\
\hline Openness & & & $\begin{array}{l}-0.0028 \\
(0.0024)\end{array}$ & $\begin{array}{l}-0.0091 \\
(0.0160)\end{array}$ & $\begin{array}{c}0.0238^{* * *} \\
(0.0092)\end{array}$ & $\begin{array}{l}-0.0026 \\
(0.0024)\end{array}$ \\
\hline $\begin{array}{l}\text { BankingCrisis } \\
\text { (Dummy) }\end{array}$ & & & $\begin{array}{c}-2.7434^{* * *} \\
(0.7915)\end{array}$ & $\begin{array}{c}-2.6657^{* * *} \\
(0.6882)\end{array}$ & $\begin{array}{c}-2.7849^{* * *} \\
(0.8818)\end{array}$ & $\begin{array}{c}-2.7649^{* * *} \\
(0.7904)\end{array}$ \\
\hline Political Risk & & & & & $\begin{array}{c}0.0397 \\
(0.0298)\end{array}$ & \\
\hline GovChange & & & & & $-0.8924^{* *}$ & \\
\hline (Dummy) & & & & & $(0.3703)$ & \\
\hline CurrencyCrisis & & & & & $-4.8892^{* * *}$ & \\
\hline (Dummy) & & & & & $(1.2392)$ & \\
\hline Debt/GDP & & & & & $\begin{array}{l}0.0252^{*} \\
(0.0139)\end{array}$ & \\
\hline Observations & 1,347 & 1,347 & 887 & 887 & 724 & 887 \\
\hline Countries & 61 & 61 & 45 & 45 & 45 & 45 \\
\hline Time FE & YES & YES & YES & YES & YES & YES \\
\hline Country FE & $\mathrm{NO}$ & NO & $\mathrm{NO}$ & YES & YES & YES \\
\hline$R^{2}$ & 0.1281 & 0.1282 & 0.3939 & 0.3475 & 0.4444 & 0.3925 \\
\hline
\end{tabular}

Note: The dependent variable is the annual growth rate of real GDP per capita, measured in percentage points. The key explanatory variable is the haircut of the final restructuring, which is carried forward for five years after crisis exit (column 1-5). In column 6, we use the average coerciveness index value over the whole default episode, also lagged for the subsequent five years. All specifications include a (non-reported) constant. Robust standard errors are given in parentheses. ${ }^{* *},{ }^{* *}$, and ${ }^{*}$ denote significance at the 1,5 , and 10 per cent levels, respectively. 